\title{
Prospective copper resources in Poland
}

\section{Introduction}

Considering the current state of knowledge and economic conditions - the resource base of the Polish copper industry may be evaluated preferably when referring to the following: (1) sediment-hosted stratiform $\mathrm{Cu}-\mathrm{Ag}$ deposits of the Fore-Sudetic Monocline, the North Sudetic Trough and the Żary Pericline, and (2) porphyry and skarn Mo-Cu-W deposits of the contact zone between the Upper Silesia and Małopolska blocks.

Given the possibilities of operation at depths previously unattainable in Polish copper mining, it is necessary to continuously analyse the prospects, not only in the direct vicinity of the mining areas, but also in the remaining part of SW Poland, in order to determine the prospective areas for copper industry. Because the demand for raw materials is continuously increasing, such systematic prospecting meets the reindustrialization trend in the EU, reflecting the importance of mining industry for economic growth (Galos et al. 2012).

The goal of the present paper is to determine the country's prospective resource base and to establish the directions of further prospecting and general exploration. Assuming clear criteria for demarcation of regions with potential prognostic, prospective and hypothetical resources in Poland (Smakowski and Szamałek 2011), the previous outlooks should be verified.

* D.Sc., Assoc. Prof., **** M.Sc., Polish Geological Institute - National Research Institute, Warsaw; e-mail: slawomir.oszczepalski@pgi.gov.pl; andrzej.chmielewski@pgi.gov.pl

** Professor, University of Warsaw, Polish Geological Institute - National Research Institute, Miedzi Copper Corporation, Warsaw; e-mail: s.speczik@uw.edu.pl

*** Ph.D., Miedzi Copper Corporation; e-mail: kmalecka@miedzicopper.com 


\section{Sediment-hosted stratiform $\mathrm{Cu}-\mathrm{Ag}$ deposits of the Fore-Sudetic Monocline and the North Sudetic Trough}

These mineral deposits occur in the contact zone between the Zechstein and Rotliegend Groups and comprise the Zechstein copper-bearing series (Fig. 1). Mineralized rock is found in the Weissliegend sandstones (Bs), the Basal Limestone (Ca0), the Kupferschiefer (T1) and the Zechstein Limestone (Ca1). They are sediment-hosted copper deposits, which contain mineralisation consisting mostly of fine-grained copper sulphides that occur as stratiform to stratabound disseminations in siliciclastic and carbonate rocks. They are polymetallic ore deposits, because silver coexists with copper, and significant amounts of lead, zinc, cobalt, molybdenum, nickel, selenium, rhenium, gold, and platinum-group metals may be also asscociated locally with copper mineralisation.

The Polish Geological Institute has conducted investigations of the Zechstein copper-bearing series in Poland since 1957, when the Lubin-Sieroszowice ore deposit was discovered as a result of a copper exploration project led by Jan Wyżykowski (Wyżykowski 1958). Subsequently, new mineral deposits were successively documented within the Lubin-

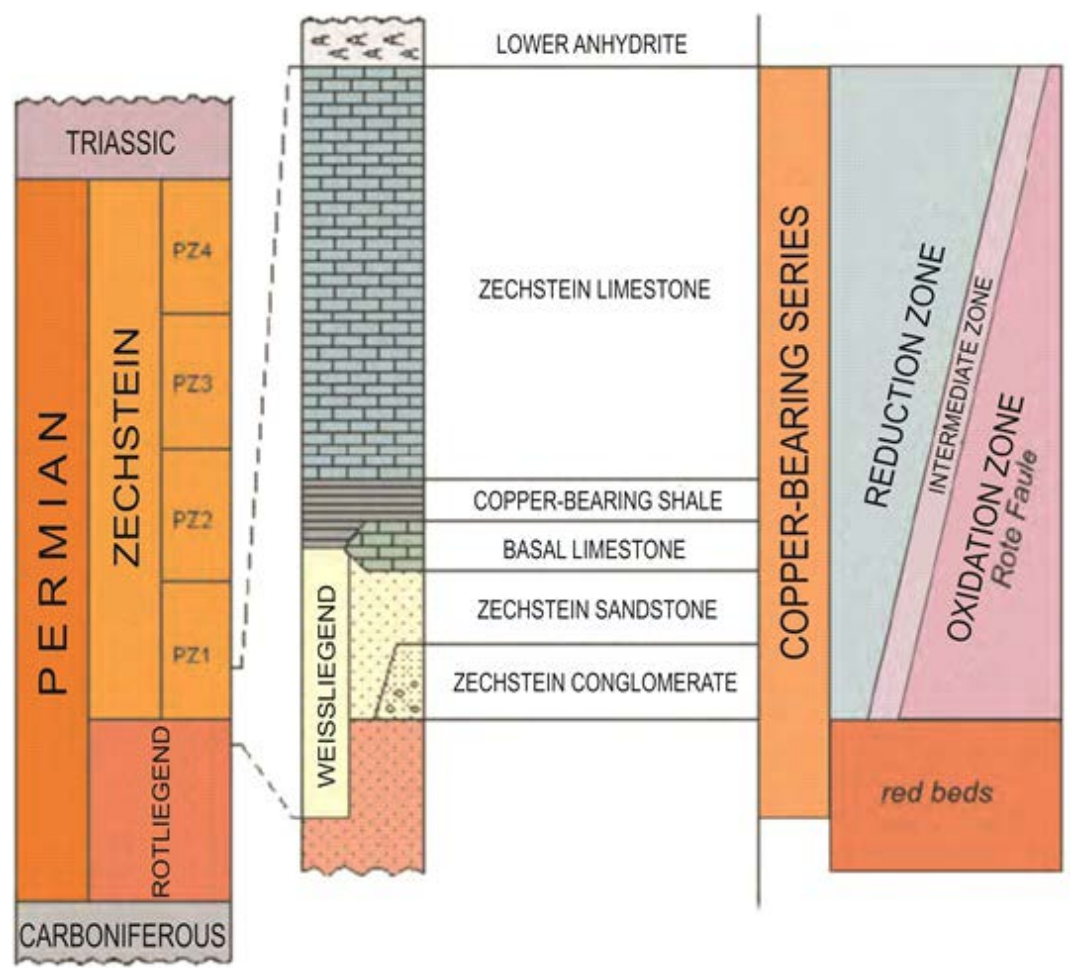

Fig. 1. Stratigraphic position of the Zechstein copper-bearing series and a distribution chart of geochemical zones

Rys. 1. Pozycja stratygraficzna cechsztyńskiej serii miedzionośnej oraz schemat rozmieszczenia stref geochemicznych 
-Sieroszowice mining district. At the same time, regional patterns in the distribution of mineralisation in the Lower Silesia and in the remaining parts of Poland were initially described (Rydzewski 1969; Wyżykowski 1971).

New prognostic evaluations were prepared after systematic examination of the boreholes of Polish Geological Institute - National Research Institute (PGI-NRI) and the oil and gas industry (Gospodarczyk 1976; Bossowski 1982; Oszczepalski and Rydzewski 1993; Rydzewski et al. 1996; Oszczepalski et al. 1996). The most important exploration guide, the close spatial association of copper-silver orebodies with the Rote Fäule oxidised rocks, constitutes a basis for the applied exploration strategy for copper ore deposits (Rydzewski 1978; Oszczepalski and Rydzewski 1983, 1991; Oszczepalski 1989, 1999; Speczik 1995). With the gradual inflow of information, the ranges of prospective areas and resource estimates became more precise in subsequent evaluations (Oszczepalski and Rydzewski 1997, 2007; Speczik et al. 1998, 2007; Wirth et al. 2007).

In recent years, sampling of several dozen additional oil and gas boreholes significantly enhanced the database used to make prognostic evaluations. Current works were initiated by the Ministry of Environment and the National Fund for Environmental Protection and Water Management, as well as are part of the funded statutory activities of PGI-NRI (Oszczepalski et al. 2010b, 2012; Oszczepalski and Speczik 2011a, b). The other work was done in cooperation between PGI-NRI and KGHM Polska Miedź SA (Speczik and Oszczepalski 2011; Speczik et al. 2011), and between PGI-NRI and Miedzi Copper (Speczik et al. 2013, 2014). Additionally, a new assessment of copper resources in Poland have been published very recently (Zientek et al. 2015), which synthesizes available information on permissive tracts and estimates the location and quantity of undiscovered copper resources associated with the Kupferschiefer series. All those latest results form the basis for a new compilation map showing the distribution of the Rote Fäule oxidation areas (Oszczepalski and Speczik 2014), and for the present evaluation.

Until 2011, the cut-off criteria defined by the Regulation of the Minister of the Environment, issued on 20 June 2005 (Dz.U. $2005 \mathrm{nr}$ 116, poz. 978) were crucial for the examination and evaluation of mineralisation and the formal definition mineral inventory (Table 1).

Table 1. Cut-off criteria for sediment-hosted stratabound copper deposits

Tabela 1. Kryteria bilansowości pokładowych stratoidalnych złóż miedzi

\begin{tabular}{|c|l|c|c|}
\hline No. & \multicolumn{1}{|c|}{ Parameter } & Unit & Threshold \\
\hline 1 & Maximum depth of the ore deposit & $\mathrm{m}$ & $1250(1500)^{*}$ \\
\hline 2 & Sample cut-off Cu grade delineating the ore deposit & $\%$ & 0.7 \\
\hline 3 & $\begin{array}{l}\text { Minimum Cu equivalent grade in composite sample. } \\
\text { Cu equivalent is calculated from the formula Cue }=(\% \mathrm{Cu})+0.01(\mathrm{~g} / \mathrm{t} \mathrm{Ag})\end{array}$ & $\%$ & 0.7 \\
\hline 4 & Minimum productivity of the ore deposit & $\mathrm{kg} / \mathrm{m}^{2}$ & $50(35)^{* *}$ \\
\hline
\end{tabular}

* The depth of $1500 \mathrm{~m}$ allowed for subeconomic resources.

** Value for subeconomic resources. 
These parameters constitute the basis for documenting mineral resources in copper ore deposits in the category of $\mathrm{C}_{2}$ or above; the calculated resources were compiled in the yearly Balance of Poland's Mineral Deposit Resources.

Currently, based on the Regulation of the Minister of the Environment dated 22 December 2011 (Dz.U. $2011 \mathrm{nr}$ 291, poz. 1712), the following threshold values of parameters defining a mineral deposit and its boundaries are in use (Table 2).

Table 2. Threshold values of parameters defining sediment-hosted stratabound copper deposit and its boundaries

Tabela 2. Graniczne wartości parametrów definiujących pokładowe stratoidalne złoża rud miedzi i ich granice

\begin{tabular}{|c|l|c|c|}
\hline No. & \multicolumn{1}{|c|}{ Parameter } & Unit & Threshold \\
\hline 1 & Maximum depth of the ore deposit & $\mathrm{m}$ & 1500 \\
\hline 2 & Sample cut-off Cu grade delineating the ore deposit & $\%$ & 0.5 \\
\hline 3 & $\begin{array}{l}\text { Minimum Cu equivalent grade in composite sample. } \\
\text { Cu equivalent is calculated from the formula Cue }(\% \mathrm{Cu})+0.01(\mathrm{~g} / \mathrm{t} \mathrm{Ag})\end{array}$ & $\%$ & 0.5 \\
\hline 4 & Minimum productivity of the ore deposit & $\mathrm{kg} / \mathrm{m}^{2}$ & 35 \\
\hline
\end{tabular}

\section{Operated copper deposits of the Fore-Sudetic Monocline}

There are six mining areas within the Lubin-Sieroszowice mining district of the Fore-Sudetic Monocline: Deep Głogów, Lubin, Małomice, Polkowice, Radwanice East, Rudna and Sieroszowice (Fig. 2). KGHM Polska Miedź SA has the mining concessions for all of them. As of 31 December 2014 and according to the cut-off criteria valid until the end of 2011 (Table 1), resources are $1446.38 \mathrm{Mt}$ of ore containing $28.37 \mathrm{Mt} \mathrm{Cu}$ and 84.03 thousand tonnes of Ag (Malon et al. 2014). In 2013, KGHM, the sole producer of copper in Poland, mined $30.647 \mathrm{Mt}$ of ore with $1.57 \% \mathrm{Cu}, 57 \mathrm{ppm} \mathrm{Ag}$, comprising 482 thousand tonnes of $\mathrm{Cu}$ and 1393 tonnes of $\mathrm{Ag}$. In the same year, the company recovered 565.2 thousand tonnes of electrolytic copper, along with 1161.1 tonnes $\mathrm{Ag}, 431.3 \mathrm{~kg} \mathrm{Au}, 26.7$ thousand tonnes $\mathrm{Pb}$, 2.8 thousand tonnes of nickel sulphate, 80.2 tonnes Se, $176.7 \mathrm{~kg}$ of Pt-Pd concentrate and 7.5 tonnes of Re, as well as sulphuric acid and copper sulphate. KGHM was the world's 10th leading copper producer and the top silver producer in 2011.

Furthermore, there are two ore deposits with inactive mines: Niecka Grodziecka and Nowy Kościół within the North Sudetic Trough, with 23.77 Mt of ore resources meeting the criteria, containing $0.26 \mathrm{Mt} \mathrm{Cu}$ and 1.08 thousand tonnes of $\mathrm{Ag}$. 


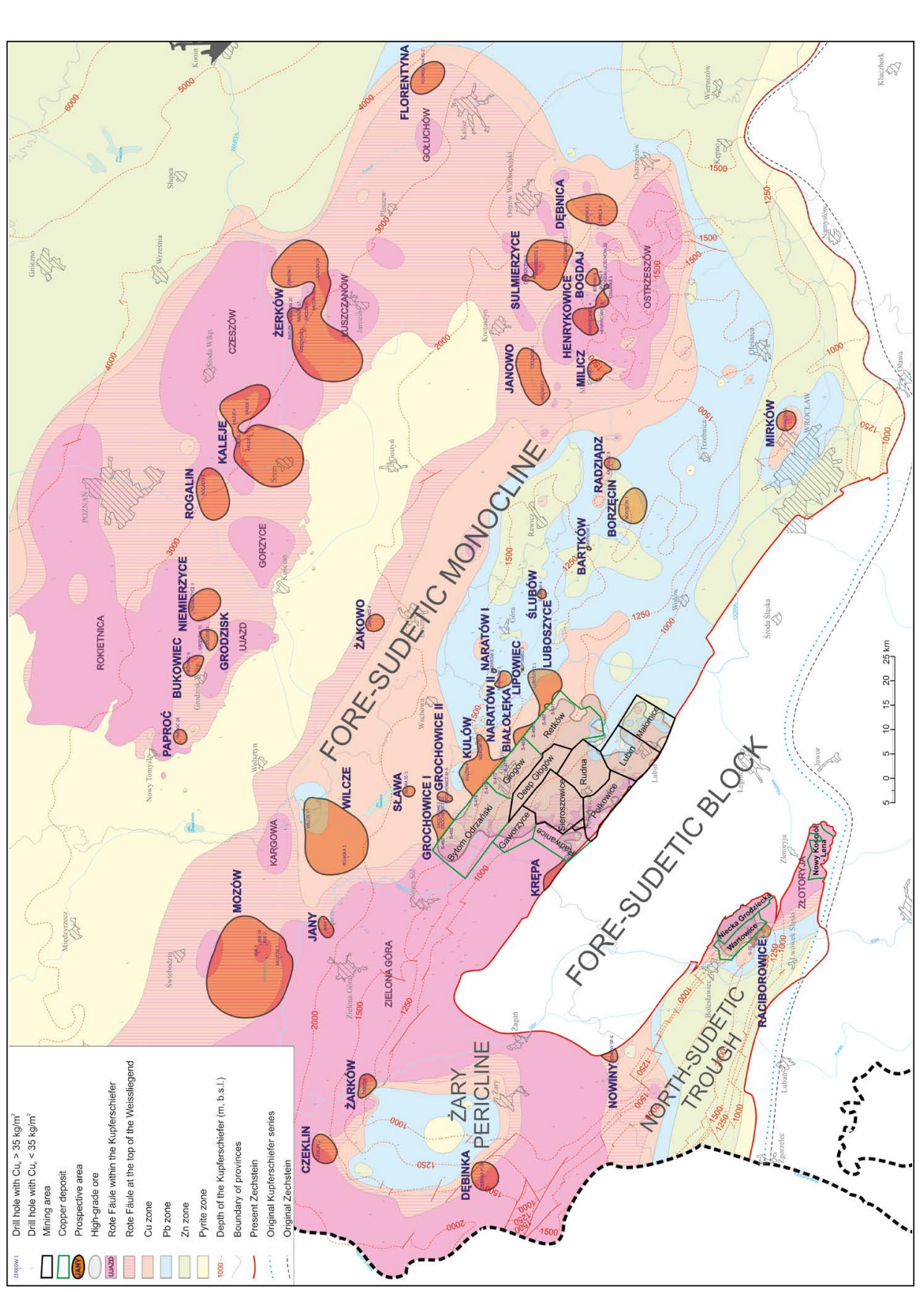




\section{Undeveloped documented copper deposits of the Fore-Sudetic Monocline and the North Sudetic Trough}

Among the undeveloped copper ore deposits with identified resources are: Bytom Odrzański, Gaworzyce, Głogów, Radwanice and Retków in the Fore-Sudetic Monocline and Wartowice in the North Sudetic Trough (Fig. 2). As of 31 December 2013, the documented resources meeting the criteria in the undeveloped ore deposits of the Fore-Sudetic Monocline are $212.50 \mathrm{Mt}$ of ore comprising 3.98 Mt of $\mathrm{Cu}$ and 13.81 thousand tonnes of $\mathrm{Ag}$. In Wartowice, the only undeveloped ore deposit of the North Sudetic Trough, there are 79.32 Mt of ore containing 1.17 Mt of $\mathrm{Cu}$ and 4.26 thousand tonnes of $\mathrm{Ag}$ (Table 3). These resources are present at various depths, ranging between 500-700 m (Radwanice), $500-1250 \mathrm{~m}$ (Wartowice), and $1000-1250 \mathrm{~m}$ in the remaining ore deposits. Apart from those resources, subeconomic resources of $809.91 \mathrm{Mt}$ of ore comprising $13.24 \mathrm{Mt} \mathrm{Cu}$ and 41.43 Mt Ag have been documented (Table 3); these resources are subeconomic because of their depth, which ranges from 1250 to $1500 \mathrm{~m}$.

Table 3. Economic and subeconomic resources of undeveloped copper deposits in the Fore-Sudetic Monocline and the North Sudetic Trough (after Malon et al. 2014)

Tabela 3. Bilansowe i pozabilansowe zasoby niezagospodarowanych złóż miedzi na monoklinie przedsudeckiej i w niecce północnosudeckiej

\begin{tabular}{|l|c|c|c|c|c|c|}
\hline \multirow{2}{*}{$\begin{array}{c}\text { Undeveloped } \\
\text { deposits }\end{array}$} & \multirow{2}{*}{$\begin{array}{c}\text { Mean Cu } \\
\text { content } \\
(\%)\end{array}$} & \multicolumn{4}{|c|}{ Economic resources } & \multicolumn{2}{c|}{ Subeconomic resources } \\
\cline { 5 - 8 } & Ore (Mt) & $\begin{array}{c}\text { Copper } \\
(\mathrm{Mt})\end{array}$ & $\begin{array}{c}\text { Silver } \\
\text { (tonnes) }\end{array}$ & $\begin{array}{c}\text { Copper } \\
\text { (Mt) }\end{array}$ & $\begin{array}{c}\text { Silver } \\
\text { (tonnes) }\end{array}$ \\
\hline Bytom Odrzański & $2.4-2.5$ & 2.25 & 0.09 & 54 & 3.27 & 6517 \\
\hline Gaworzyce & $0.9-3.0$ & 54.39 & 1.28 & 1926 & 0.20 & 314 \\
\hline Głogów & 2.0 & - & - & - & 4.78 & 19550 \\
\hline Radwanice & $2.5-2.7$ & 18.57 & 0.46 & 795 & 0.09 & 11 \\
\hline Retków & $1.8-2.9$ & 137.29 & 2.15 & 11031 & 4.70 & 14451 \\
\hline Wartowice & $1.2-1.5$ & 79.32 & 1.16 & 4260 & 0.20 & 582 \\
\hline
\end{tabular}

The Radwanice and Gaworzyce copper deposits with indicated resources $\left(\mathrm{C}_{1}\right.$ category) are adjacent to the mining concession area of KGHM, and are currently considered as reserve areas for copper industry (Wirth et al. 2007). All the remaining undeveloped copper deposits (Bytom Odrzański, Głogów, Retków), with inferred and indicated resources $\left(\mathrm{C}_{1}\right.$ and $\mathrm{C}_{2}$ categories) adjacent to the northern margin of the mining areas are considered to be the most prospective resource base for copper ore mining. Because of this, KGHM has been granted concessions for detailed exploration of the Gaworzyce, Radwanice, Głogów and Retków-Ścinawa areas (Fig. 3). Leszno Copper, on the other hand, had been granted 
concession for the detailed exploration of the Bytom Odrzański deposit; however, this decision has been withdrawn pending the outcome of the appeal by KGHM.

\section{Prospective areas outside of documented copper deposits}

Prospective areas have been classified as prognostic, prospective, or hypothetical using several criteria including: their location in relation to the recognised copper ore deposits, their depth, and the number of positive boreholes with positive intercepts (Table 4). Resources immediately adjacent to the documented copper ore deposits are classified as prognostic. Resources distant from documented mineral deposits and identified by more than one borehole at with a mineralized intercept at depths $<2000 \mathrm{~m}$ have been classified as prospective. Hypothetical resources include those areas identified by a single borehole with a mineralized intercept at depths $<2000 \mathrm{~m}$ and all areas with resources at the depths $>2000 \mathrm{~m}$ regardless of the number of positive boreholes.

Table 4. Criteria for classification of undiscovered resources within prospective areas

Tabela 4. Kryteria podziału nieodkrytych zasobów na obszarach perspektywicznych

\begin{tabular}{|l|c|c|c|}
\hline $\begin{array}{c}\text { Category of } \\
\text { resources }\end{array}$ & $\begin{array}{c}\text { Location of the area } \\
\text { in relation to documented } \\
\text { copper deposits }\end{array}$ & $\begin{array}{c}\text { Depth of the ore-bearing } \\
\text { series } \\
(\mathrm{m})\end{array}$ & $\begin{array}{c}\text { Number of boreholes with } \\
\text { Cue productivity } \\
\geq 35 \mathrm{~kg} / \mathrm{m}^{2}\end{array}$ \\
\hline Prognostic & Proximal area & $<2000$ & $\geq 1$ \\
\hline Prospective & Distal area & $<2000$ & $>1$ \\
\hline \multirow{2}{*}{ Hypothetical } & Distal area & $<2000$ & 1 \\
\cline { 2 - 4 } & \multirow{2}{*}{$*$} & $>2000$ & $\geq 1$ \\
\hline
\end{tabular}

In the current evaluation, the edges of the mineral deposits are assumed to correspond to the $35 \mathrm{~kg} / \mathrm{m}^{2}$ contour of $\mathrm{Cu}_{\mathrm{e}}$ productivity (or $\mathrm{Cu}$, if the $\mathrm{Ag}$ content was not examined) (Fig. 2). Based on the threshold values of parameters defining the mineral deposit and its boundaries (Table 2), the presumed copper and silver resources categorised as prognostic, prospective and hypothetical are estimated for the individual areas (Table 5). Due to the sparse and irregular grid of the examined boreholes as well as the geometric data interpolation, the boundaries of the prospective areas and the resource estimates should be considered tentative. New information, either from new examinations of historical boreholes or from new prospecting drillings, could significantly increase or decrease the estimated resources. 
12

Oszczepalski et al. 2016 / Gospodarka Surowcami Mineralnymi - Mineral Resources Management 32(2), 5-30

Table 5. Undiscovered copper and silver resources of the prospective areas

Tabela 5. Nieodkryte zasoby miedzi i srebra na obszarach perspektywicznych

\begin{tabular}{|c|c|c|c|c|c|c|c|c|}
\hline $\begin{array}{l}\text { Resource } \\
\text { category }\end{array}$ & $\begin{array}{l}\text { Prospective } \\
\text { area }\end{array}$ & $\begin{array}{c}\text { Area } \\
\left(\mathrm{km}^{2}\right)\end{array}$ & $\begin{array}{c}\text { Depth } \\
\text { range } \\
(\mathrm{MBGL})\end{array}$ & $\begin{array}{c}\text { Average } \\
\text { thickness } \\
\text { (m) }\end{array}$ & $\begin{array}{c}\text { Average } \\
\mathrm{Cu} \\
\text { content } \\
(\%)\end{array}$ & $\begin{array}{c}\mathrm{Cu} \\
\text { resources } \\
(\mathrm{Mt})\end{array}$ & $\begin{array}{c}\text { Average } \\
\text { Ag } \\
\text { content } \\
\text { (ppm) }\end{array}$ & $\begin{array}{c}\mathrm{Ag} \\
\text { resources } \\
\text { (tonnes) }\end{array}$ \\
\hline \multirow{6}{*}{ Prognostic } & Białołęka & 13.80 & $1500-1600$ & 2.11 & 1.07 & 0.779 & 44 & 3203 \\
\hline & Grochowice I & 15.80 & $1600-1700$ & 1.10 & 2.59 & 1.125 & 170 & 7386 \\
\hline & Krępa & 9.61 & $400-500$ & 3.32 & 0.72 & 0.574 & 16 & 1276 \\
\hline & Kulów & 48.64 & $1500-1700$ & 1.59 & 3.14 & 6.071 & 86 & 16628 \\
\hline & Luboszyce & 36.19 & $1500-1600$ & 1.34 & 0.97 & 1.176 & 57 & 6910 \\
\hline & Raciborowice & 7.78 & $900-1500$ & 3.75 & 0.79 & 0.576 & 24 & 1937 \\
\hline \multicolumn{2}{|c|}{ Total prognostic resources } & 131.82 & $400-1700$ & \multicolumn{3}{|c|}{10.30} & \multicolumn{2}{|c|}{37340} \\
\hline \multirow{4}{*}{ Prospective } & Dębnica & 49.80 & $1600-1800$ & 0.51 & 6.21 & 3.943 & 167 & 10604 \\
\hline & Henrykowice & 28.4 & $1400-1700$ & 1.08 & 1.73 & 1.327 & 34 & 2396 \\
\hline & Janowo & 50.70 & $1600-1900$ & 1.11 & 1.64 & 2.307 & 36 & 5065 \\
\hline & Sulmierzyce & 69.75 & $1600-1900$ & 2.13 & 2.18 & 8.097 & 26 & 9657 \\
\hline \multicolumn{2}{|c|}{ Total prospective resources } & 198.65 & $1400-1900$ & \multicolumn{3}{|c|}{15.67} & \multicolumn{2}{|c|}{27722} \\
\hline \multirow{16}{*}{$\begin{array}{l}\text { Hypothetical } \\
<2000 \mathrm{~m}\end{array}$} & Bartków & 0.52 & $1300-1400$ & 0.32 & 4.18 & 0.017 & 71 & 29 \\
\hline & Bogdaj & 7.50 & $1400-1600$ & 1.58 & 1.52 & 0.450 & 34 & 1007 \\
\hline & Borzęcin & 31.70 & $1400-1600$ & 0.51 & 4.91 & 1.984 & - & - \\
\hline & Czeklin & 23.75 & $1600-1800$ & 0.23 & 10.54 & 1.439 & - & - \\
\hline & Dębinka & 25.64 & $1400-1600$ & 2.30 & 0.69 & 1.017 & 44 & 6487 \\
\hline & Grochowice II & 2.35 & $1600-1700$ & 1.52 & 1.60 & 0.143 & 23 & 205 \\
\hline & Lipowiec & 0.12 & $1400-1500$ & 0.60 & 2.06 & 0.004 & 64 & 11 \\
\hline & Milicz & 13.60 & $1500-1700$ & 1.86 & 0.89 & 0.563 & 26 & 1644 \\
\hline & Mirków & 12.84 & $1100-1300$ & 1.17 & 1.56 & 0.023 & - & - \\
\hline & Naratów I & 0.25 & $1500-1600$ & 0.52 & 2.07 & 0.007 & 86 & 28 \\
\hline & Naratów II & 7.88 & $1400-1500$ & 0.55 & 3.99 & 0.432 & 319 & 3456 \\
\hline & Nowiny & 5.70 & $400-600$ & 0.47 & 2.64 & 0.177 & 100 & 670 \\
\hline & Radziądz & 6.25 & $1600-1800$ & 1.65 & 0.93 & 0.240 & 7 & 180 \\
\hline & Sława & 9.48 & $1900-2000$ & 0.45 & 1.92 & 0.205 & 161 & 1717 \\
\hline & Ślubów & 2.50 & $1300-1400$ & 0.20 & 9.08 & 0.113 & 164 & 205 \\
\hline & Żarków & 13.76 & $1000-1500$ & 3.01 & 1.34 & 1.387 & 22 & 2278 \\
\hline \multicolumn{2}{|c|}{$\begin{array}{l}\text { Total hypothetical resources } \\
\qquad<2000 \mathrm{~m}\end{array}$} & 163.84 & $400-2000$ & \multicolumn{3}{|c|}{8.20} & \multicolumn{2}{|c|}{17917} \\
\hline
\end{tabular}


Table 5. cont.

Tabela 5. cd.

\begin{tabular}{|c|c|c|c|c|c|c|c|c|}
\hline $\begin{array}{l}\text { Resource } \\
\text { category }\end{array}$ & $\begin{array}{l}\text { Prospective } \\
\text { area }\end{array}$ & $\begin{array}{l}\text { Area } \\
\left(\mathrm{km}^{2}\right)\end{array}$ & $\begin{array}{l}\text { Depth } \\
\text { range } \\
\text { (MBGL) }\end{array}$ & $\begin{array}{l}\text { Average } \\
\text { thickness } \\
\text { (m) }\end{array}$ & $\begin{array}{c}\text { Average } \\
\mathrm{Cu} \\
\text { content } \\
(\%)\end{array}$ & $\begin{array}{l}\mathrm{Cu} \\
\text { resources } \\
(\mathrm{Mt})\end{array}$ & $\begin{array}{c}\text { Average } \\
\text { Ag } \\
\text { content } \\
(\mathrm{ppm})\end{array}$ & $\begin{array}{c}\mathrm{Ag} \\
\text { resources } \\
\text { (tonnes) }\end{array}$ \\
\hline \multirow{12}{*}{$\begin{array}{l}\text { Hypothetical } \\
>2000 \mathrm{~m}\end{array}$} & Bukowiec & 12.17 & $2700-2800$ & 0.60 & 2.87 & 0.524 & 89 & 1625 \\
\hline & Florentyna & 88.58 & $3200-4200$ & 1.00 & 2.66 & 5.891 & 33 & 7308 \\
\hline & Grodzisk & 10.35 & $2700-2800$ & 1.07 & 3.54 & 0.980 & 94 & 2603 \\
\hline & Jany & 44.43 & $2000-2200$ & 1.34 & 2.13 & 3.170 & - & - \\
\hline & Kaleje & 195.40 & $2700-3400$ & 2.30 & 2.75 & 30.904 & 26 & 29218 \\
\hline & Mozów & 370.03 & $2100-2700$ & 2.33 & 2.73 & 58.843 & 51 & 43971 \\
\hline & Niemierzyce & 32.74 & $2700-2900$ & 1.00 & 4.16 & 3.405 & 21 & 1719 \\
\hline & Paproć & 6.39 & $2500-2700$ & 0.10 & 17.27 & 0.276 & 421 & 673 \\
\hline & Rogalin & 53.84 & $2900-3200$ & 1.90 & 1.42 & 3.631 & 7 & 1790 \\
\hline & Wilcze & 162.21 & $2000-2500$ & 0.49 & 5.15 & 10.233 & 537 & 106706 \\
\hline & Żakowo & 10.29 & $2100-2300$ & 0.40 & 3.36 & 0.346 & 45 & 463 \\
\hline & Żerków & 263.80 & $2600-3700$ & 1.75 & 2.29 & 26.377 & 58 & 66932 \\
\hline \multicolumn{2}{|c|}{$\begin{array}{l}\text { Total hypothetical resources } \\
\qquad>2000 \mathrm{~m}\end{array}$} & 1250.23 & $2000-4200$ & \multicolumn{3}{|c|}{144.58} & \multicolumn{2}{|c|}{263008} \\
\hline \multicolumn{2}{|c|}{$\begin{array}{l}\text { Total prognostic, } \\
\text { prospective and hypothetical }\end{array}$} & 1744.54 & $400-4200$ & \multicolumn{3}{|c|}{178.75} & \multicolumn{2}{|c|}{345987} \\
\hline
\end{tabular}

\section{Recommendations and problems}

Even though the Kupferschiefer underlies large areas of Poland, undiscovered economic deposits are likely to exist only in SW Poland, where many prospective areas are mapped (Fig. 2) and for which resources of copper and silver have been estimated (Table 5). These prospective areas can be differentiated into three groups based on the depth to the Kupferschiefer series and the number of holes available for examination.

The first group, with the shallowest areas, include: Krępa, Bartków, Lipowiec, Mirkow, Naratów II, Nowiny, Raciborowice, Ślubów, and Żarków. In these areas, the base of the copper-bearing series occurs above the depth of $1500 \mathrm{~m}$. There are only single holes available for each area, apart from Raciborowice; therefore, these areas are classified as prospective areas with hypothetical resources. 


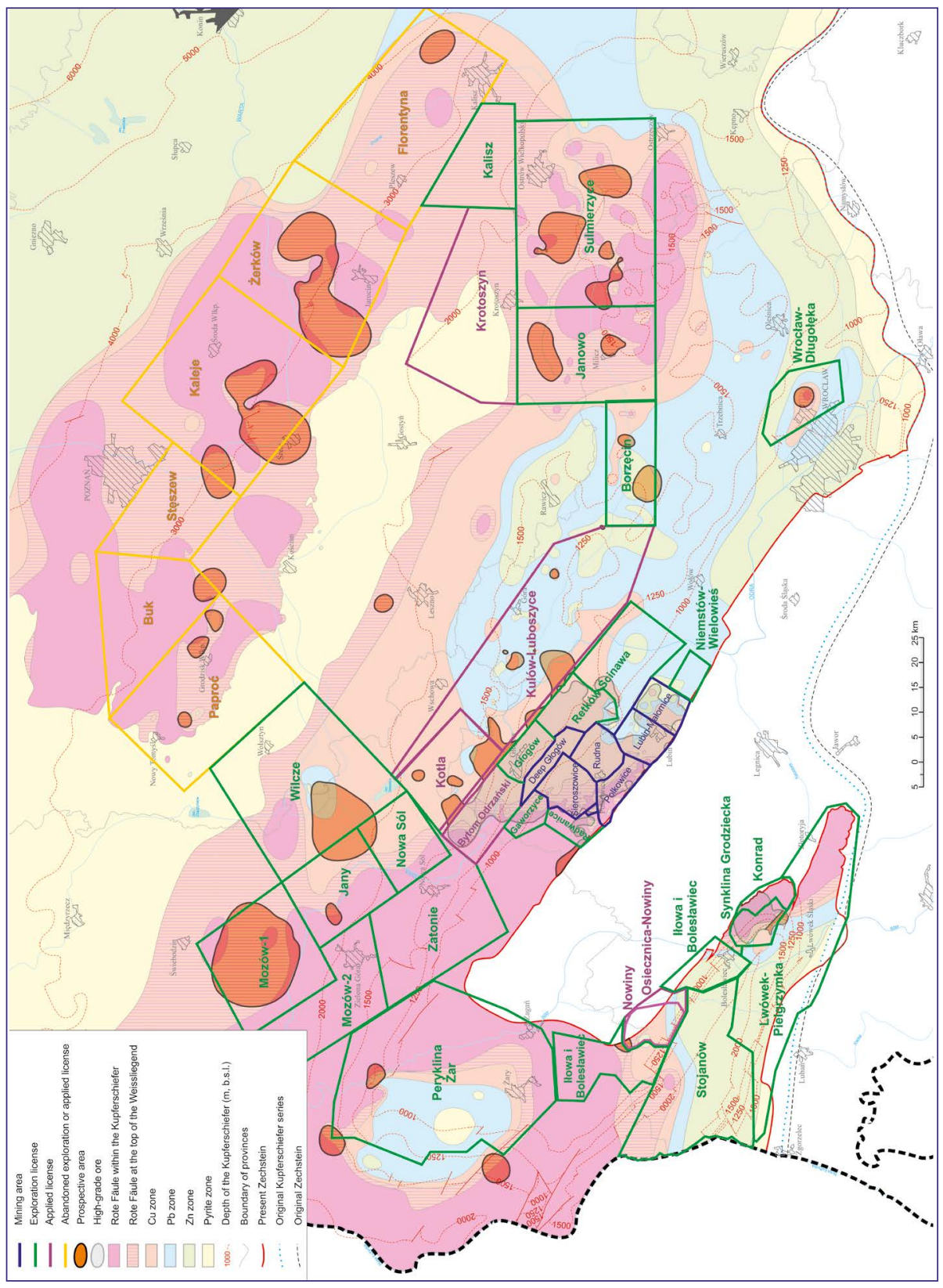

离

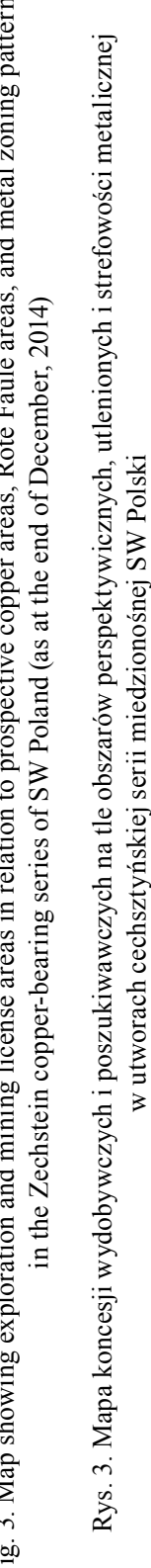


The second group includes 17 prospective areas where the Kupferschiefer occurs at depths of 1500-2000 m. Only 4 areas, Dębnica, Henrykowice, Janowo, Sulmierzyce, are recognized as having prospective resources. The remaining areas are classified as having hypothetical resources because mineralization was found in single holes.

The third group consists of areas with the mineralization horizon at depth below $2000 \mathrm{~m}$, of which 5 areas (Grodzisk, Kaleje, Mozów, Wilcze and Żerków) have been drilled by more than one hole.

The most important prospective areas, recommended first for further exploration, are those areas of prognostic resource adjacent to the Lubin-Sieroszowice: Grochowice I, Kulów, Białołęka, and Luboszyce (Oszczepalski and Speczik 2014; Speczik et al. 2014). These areas, which extend over $114 \mathrm{~km}^{2}$, may contain $9 \mathrm{Mt}$ of copper and 34000 tonnes of $\mathrm{Ag}$ at depths of 1500 to $1700 \mathrm{~m}$, with thickness ranging from 1.1 to $2.1 \mathrm{~m}$, and with average grade in the range of $0,97-3,14 \% \mathrm{Cu}$ and $44-170 \mathrm{ppm} \mathrm{Ag}$. These resources are estimated for the areas with the limits of the geometric data interpolation constrained by 15 positive boreholes and a few dozen negative ones in the surrounding areas. Therefore, it should be noted, that irregular network of examined drill holes tended to simplify the ranges of prospects and to overestimate resource evaluation.

The trend of increasing copper concentration in the direction of the Lubin-Sieroszowice deposit allowed us to assume that prospective areas (Grochowice I, Kulów, Białołęka, and Luboszyce) tend to connect with Bytom Odrzański, Głogów and Retków deposits. In this area, continuation of Bytom Odrzański deposits is expected, not only towards the prospective area of Grochowice I (within present hypothetical limits), but also towards the north-west, in the direction of Wilcze, Jany and Mozów prospective areas. In order to delineate the predicted copper zone, continued research of available archival core drillings and continuation of drilling and geophysical exploration will be necessary.

This predicted continuation underlies several license areas: Kotla, Niechlów, Nowa Sól, Wilcze, Jany, Mozów-1, and Kulów-Luboszyce (Fig. 3). The first six concessions were applied by Leszno Copper, Zielona Góra Copper and Wilcze Copper companies. The Kulów-Luboszyce concession is requested by KGHM Polska Miedź SA Preliminary results of the first drilling completed in the area of Nowa Sól support the forecasts.

Near the areas with prognostic resources, there are small areas with hypothetical resources, such as: Borzęcin, Grochowice II, Naratów I and II, Lipowiec, Sława and Ślubów, known by single holes, with Zechstein base depth ranging from 1400 to $2000 \mathrm{~m}$. The importance of the intercepts in these areas may increase if connections with areas of prognostic resources can be established.

The principal geological barriers constituting a potential threat to future exploration works within areas of prognostic and prospective resources and the possible future development of selected areas are: limited amount of geological information, rare and irregular drill hole network with available cores, drillings carried out in accordance with the methodology of gas and oil exploration and lower thickness of the ore interval. Unfavourable geological and mining conditions include: depth (1500-1700 m), high temperature of the rock mass 
$\left(45-55^{\circ} \mathrm{C}\right)$, and gas and oil threats (hydrocarbons, nitrogen, helium). In these areas, natural gas deposits have been documented (Grochowice, Kulów, Dębina and Lipowiec). For these reasons, the economic barriers may be the high cost of mineral extraction (including tax on the extraction), poor air quality, natural impoverishment of ore being produced, and the depth of its occurrence.

The Krępa area, located within the oxidized Zielona Góra Rote Fäule field at the border with Fore-Sudetic Block, has been defined by extrapolation of a trend determined by S-16 drill hole, located on the Radwanice concession (Fig. 2). The occurrence of copper mineralization high in the Zechstein Limestone in this hole and the presence of oxidized profiles in its surroundings means the chances of finding rich deposits in the Krępa area are relatively low, despite the possibility of occurrence of Au-Pt-Pd mineralization, very favourable depth to the mineralized series $(400-500 \mathrm{~m})$, low temperatures in the Zechstein base $\left(20-30^{\circ} \mathrm{C}\right)$, and the lack of gas hazards.

An interesting prospective area is the Raciborowice area in the North Sudetic Trough, adjacent to the Wartowice ore deposit. According to the economic viability criteria in force until 2011, the holes southwest of the Wartowice deposit were considered negative as they do not meet the above mentioned criteria (Table 3). However, according to the recommended parameters defining the boundaries of deposit (Table 2), the drill holes from the Raciborowice area meet minimum $\mathrm{Cu}_{\mathrm{e}}$ content parameter. In this area, $0.576 \mathrm{Mt}$ of copper and 1,937 tonnes of $\mathrm{Ag}$ can be expected in an interval that averages $3.75 \mathrm{~m}$ thick, and has an average grade of $0.79 \% \mathrm{Cu}$ and $24 \mathrm{ppm} \mathrm{Ag}$. Due to the increased abundance (in the range of 8.22 to $18.72 \mathrm{~kg} / \mathrm{m}^{2} \mathrm{Cu}_{\mathrm{e}}$ ) of holes surrounding the area and the likelihood of its continuation in the southeast, an extension of the prospective area can be expected in the direction of the Nowy Kościół deposit, forming a Kupferschiefer belt of that could be 5-10 km wide, with mineralization at depth of $900-1500 \mathrm{~m}$ in favorable geological and mining conditions. It is likely that this hypothesis will be verified in the future, as the discussed area, located at the junction of three exploration licenses owned by KGHM (Synklina Grodziecka and Konrad) and Leszno Copper (Lwówek-Pielgrzymka), is already the site of an ongoing exploration drilling project (Lipień et al. 2014).

Of the prospective areas away from the documented copper deposits, but not lying at great depth, the prospective areas Nowiny (at a depth of 400-600 m), Żarków (1000$-1500 \mathrm{~m}$ ) and Mirków (1100-1300 m) deserve special attention.

The current extent of the Nowiny prospective area, located on the boundary between the North Sudetic Trough and the Żary Pericline (Bachowski et al. 2011), does not have great potential, but there is a possibility that the prospective area extends to the south east and west to the known Spremberg-Weisswasser deposits in Germany. If true, the prospective resources would increase to nearly $2 \mathrm{Mt}$ of copper. The geologic and mining conditions are very favorable for development because the depth of the copper-bearing series is insignificant, the host rock temperature of the mineralized interval is low (less than $40^{\circ} \mathrm{C}$ ), and there are no gas hazards. Because this area is located on the boundary of the Ilowa-Boleslawiec exploration concession, granted to the Silesian-Cracovian Metal Mining Company, and the 
Osiecznica-Nowiny and Nowiny concessions applied by KGHM Polska Miedź SA, verification of this prediction is expected shortly.

The Żarków prospective area, located at the transition from Żary Pericline to Fore-Sudetic Monocline, forms an embayment in Zielona Góra Rote Fäule area, open to the south. There is no gas hazard, but the host-rock temperature at the base Zechstein is quite high $\left(50-60^{\circ} \mathrm{C}\right)$.

The Mirków prospective area (SE part of the Fore-Sudetic Monocline) is surrounded by holes, in which the Kupferschiefer series is characterized by lead-zinc mineralization. This area does not have gas hazards and the host-rock temperature is a reasonable $40-50^{\circ} \mathrm{C}$. The proximity of Wroclaw and its suburbs pose a significant limitation in land-use planning of the Mirków area. The Mirkow and Żarków prospective areas underlie concessions granted to Amarante Investments Company.

Sulmierzyce, Dębnica, Janowo and Henrykowice prospective areas, located in the eastern part of Fore-Sudetic Monocline, are the remaining prospects with resources at a depth $<2000 \mathrm{~m}$. The association of rich copper mineralization with the large Ostrzeszów Rote Fäule area and numerous small, nearby oxidized fields is comparable (in both the degree of concentration and the relative position of the redox boundary in the horizontal and vertical distribution) to known mineralization in the western part of the Lubin-Sieroszowice deposit. Even though mineralized intercepts is only known from 12 drill holes, the total mineralized areas is almost $200 \mathrm{~km}^{2}$ and has prospective resources of $16 \mathrm{Mt}$ of copper and 28 thousand tonnes of $\mathrm{Ag}$ at depths from 1400 to $1900 \mathrm{~m}$. In seven drill holes, $\mathrm{Cu}_{\mathrm{e}}$ (or $\mathrm{Cu}$ ) content significantly exceeds $50 \mathrm{~kg} / \mathrm{m}^{2}$, with maximum values in the following drill holes: Sulmierzyce 1 224.94, Dębnica $1-89.48$, Henrykowice $4-83.66$ and Chruszczyn $3-71.08 \mathrm{~kg} / \mathrm{m}^{2}$. The density of drilling allows the possibility that these four areas may actually be continuous and could be connected with neighboring prospective smaller areas, such as Milicz and Bogdaj (Fig. 2).

In order to delineate the extent of the potentially important parts of these prospective areas, these areas are currently being explored by drilling on Janowo and Sulmierzyce exploration licenses, granted to the Ostrzeszów Copper Company (Fig. 3). Geological and mining conditions that could limit the development of these areas include: the depth exceeding $1500 \mathrm{~m}$, high host-rock temperature $\left(50-60^{\circ} \mathrm{C}\right)$, and the presence of natural gas (Bogdaj-Uciechów, Brzostowo, Henrykowice, Janowo, Tarchały and Wierzchowice gas deposits).

In addition to the areas with a copper-bearing series lying at relatively shallow depths, several prospective areas were also designated at depths exceeding $2000 \mathrm{~m}$. the most interesting are Mozów, Kaleje and Żerków areas, adjacent to large Rote Fäule areas at both sides of the Wolsztyn basement ridge (Fig. 2). These prospective areas are characterized by significant copper and silver hypothetical resources (Table 3).

The Mozów prospective area covers an area of $370 \mathrm{~km}^{2}$ and could contain approx. 59 million tons copper and 44 thousand tonnes of $\mathrm{Ag}$ in an interval having an average thickness of $2.33 \mathrm{~m}$ and an average grade of $2.73 \% \mathrm{Cu}$ and $51 \mathrm{ppm} \mathrm{Ag}$. The depth of the base of Zechstein varies from 2100 to $2700 \mathrm{~m}$. The boundary of this area and hypothetical resources 
are based on intercepts in four holes (Mozów 1, and Kije 2, 9 and 10); the richest, Kije 9 , has a $\mathrm{Cu}_{\mathrm{e}}$ value of $274 \mathrm{~kg} / \mathrm{m}^{2}$.

The Kaleje area, covering $195 \mathrm{~km}$, has hypothetical resources of $31 \mathrm{Mt}$ of copper and 29 thousand tonnes of silver at depths between $2700-3400 \mathrm{~m}$. The mineralized interval has an average thickness of $2.3 \mathrm{~m}$ and an average grade of $2.75 \% \mathrm{Cu}$ and $26 \mathrm{ppm} \mathrm{Ag}$.

Similarly, the Żerków area, covering $264 \mathrm{~km}^{2}$, amounts approximately $26 \mathrm{Mt}$ of copper and 67 thousand tonnes of $\mathrm{Ag}$ in an averaged interval of $1.75 \mathrm{~m}$ and a grade $2.29 \% \mathrm{Cu}$ and $58 \mathrm{ppm} \mathrm{Ag}$, at depths between $2600-3700 \mathrm{~m}$.

Despite favourable tonnage and grade characteristics, the mineralized rocks in the Mozów, Kaleje and Żerków areas would be difficult to development because the copper-bearing series is twice as deep as the active mines in the Lubin-Sieroszowice mining district. However, the Mozów area, at the shallowest depth, is still interesting place for the exploration of copper and silver, as a new drill hole, Mozów 1-C1, confirms the presence of extensive chalcocite mineralization. As in other drill holes of this area, the ore interval combines the upper part of the Kupferschiefer and the lower part of the Zechstein Limestone, lying on the gold-enriched oxidized portion of the lowermost Kupferschiefer horizon (Krzemiński and Speczik 2013).

Currently, on the prospective areas Mozów, Sulmierzyce, and Janowo, drilling is conducted on the exploration licenses granted to the Mozów Copper and Ostrzeszów Copper Company. Recently, a new drilling program was also recently started by the company Zielona Góra Copper in the Jany, Zatonie and Nowa Sól concession areas to confirm the continuation of the high-grade mineralization extending possibly from the Bytom Odrzański deposit towards the Mozów area.

Our discussion of the factors that would affect the development of Mozów area and other deep seated prospective areas reflects current economic and technological conditions. If global demand for raw materials increases dramatically and new technologies for deep mining are developed, the outlook for development will be quite different. Certainly, mining at depths greater than $2000 \mathrm{~m}$ will be hampered by high host-rock temperature $\left(50-65^{\circ} \mathrm{C}\right)$, large rock pressure, and possible accumulations of nitrogen gas mixed with hydrocarbons in the Rotliegend and lowermost Zechstein sediments, and crude oil in the Main Dolomite (e.g. in the Kije and Mozów vicinity). These problems may be addressed when the automation technology and remote control of machines in air-conditioned rooms are feasible.

However, bigger obstacles to development for both shallow and deep resources may be taxation and the legal system. Tax burden imposed on the investor causes a delay in the return of investment. This can significantly affect decisions on mine construction. Certainly it is impossible to avoid the tax liability, but you can move the tax burden from the design of the plant to the operational phase of the mine. This solution would certainly encourage many investors to conduct drilling or invest in the development of copper mines. 


\section{Porphyry Cu-Mo-W and skarn prospective areas at the contact zone between the Upper Silesia and Małopolska blocks}

The first geophysical and drilling investigations along the NE rim of the Upper-Silesian Coal Basin were undertaken by the Geological Institute in 1954-1957, and subsequently by the Polish Geological Institute and the Geological Enterprise of Cracow. Dozens of geological conveys have been completed; their main goal during the first stages of work was to explore the MVT-type $\mathrm{Zn}-\mathrm{Pb}$ ore deposits in the Mesozoic rocks. The preliminary results led to drilling the Myszków P-1 borehole in 1966, which penetrated numerous porphyry dykes cutting metamorphic slates and granitoids (Ekiert 1971; Piekarski 1971). These results encouraged geologists to drill down to the footwall rocks to look for the porphyry-related mineralization. As a result, porphyry Mo-W-Cu ore deposit was discovered in the Precambrian-Palaeozoic basement concealed under Mesozoic platform and Cenozoic cover sediments in the vicinity of Myszków, where category $\mathrm{C}_{2}$ resources were delineated (Piekarski et al. 1993). Originally estimated resources in an area of about $0.5 \mathrm{~km}^{2}$ at a depth of $1000 \mathrm{~m}$ were $380 \mathrm{Mt}$ of ore containing 550 thousand tonnes of $\mathrm{Cu}, 230$ thousand tonnes of $\mathrm{Mo}$, and 180 thousand tonnes of $\mathrm{W}$. Average grades were $0.152 \% \mathrm{Cu}, 0.049 \% \mathrm{Mo}\left(0.156 \mathrm{Mo}_{\mathrm{e}}\right)$, and $0.041 \% \mathrm{~W}$. Subsequent studies have enlarged the amount of known resources to be more than $550 \mathrm{Mt}$ of ore containing 804 thousand tonnes of $\mathrm{Cu}, 295$ thousand tonnes of Mo, and 238 thousand tonnes of $\mathrm{W}$. Subeconomic resources amount to 771 thousand tonnes of $\mathrm{Cu}$, 298 thousand tonnes of Mo, and 212 thousand tonnes of W (Malon et al. 2014). Its geology, mineral assemblages and metal zonation were examined in detail (Ślósarz 1982, 1993; Lasoń 1992; Markiewicz et al. 1993; Podemski et al. 2001; Buła et al. 2002; Karwowski et al. 2005; Truszel et al. 2006). The mineralization is fracture-controlled, typically consisting of veinlets containing copper sulphides (mostly chalcopyrite), pyrite, molibdenite and scheelite. Mineralisation occurs in both the intrusive and surrounding host rocks, tending to be confined to the alteration zones.

Subsequently, four prospective areas (Mrzygłód, Zawiercie, Pilica and Będkowska Valley) have been delineated (Harańczyk 1980; Górecka and Nowakowski 1979; Harańczyk et al. 1980; Piekarski 1983; Nieć 1988), but recompilation of the exploration data demarcated eight prospective areas with porphyry $\mathrm{Cu}-\mathrm{Mo}-\mathrm{W}$ mineralization and associated skarns: Mysłów, Nowa Wieś Żarecka, Myszków, Mrzygłód, Żarki-Kotowice, Zawiercie, Pilica, and Będkowska Valley (Habryn et al. 1994; Piekarski 1994a, b; Markowiak et al. 1994; Markowiak 2005; Oszczepalski et al. 2008, 2010a).

\section{Recommendations and limitations}

The current evaluation of the copper ore quality has been conducted in conformity with the threshold values of the parameters defining a mineral deposit and its boundaries for por- 
phyry Mo-W-Cu, according to criteria approved by the Minister of the Environment (Dz.U., $2011 \mathrm{nr}$ 291, poz. 1712). These criteria are summarized in Table 6.

The distribution of molybdenum as the significant metal co-occurring with copper is taken into account by using the equivalent molybdenum $\mathrm{Mo}_{\mathrm{e}}$ content parameter for the prognostic copper analysis.

Table 6. Threshold values of parameters defining porphyry Mo-W-Cu deposits and their boundaries

Tabela 6. Graniczne wartości parametrów definiujących porfirowe złoża rud Mo-W-Cu i ich granice

\begin{tabular}{|c|l|c|c|}
\hline No. & \multicolumn{1}{|c|}{ Parameter } & Unit & Threshold \\
\hline 1 & Maximum depth of the mineral deposit & $\mathrm{m}$ & 1200 \\
\hline 2 & $\begin{array}{l}\text { Minimum Mo equivalent grade taking into account the tungsten }(\mathrm{W}) \text { and copper } \\
(\mathrm{Cu}) \text { content of the sample delineating the ore-bearing interval. Mo equivalent } \\
\text { is calculated from the formula Moe }=(\% \mathrm{Mo})+1.5(\% \mathrm{~W})+0.2(\% \mathrm{Cu})\end{array}$ & 0.1 \\
\hline 3 & $\begin{array}{l}\text { Minimum Mo equivalent grade in the profile of a demarcated part (block) } \\
\text { of the deposit }\end{array}$ & $\%$ & 0.1 \\
\hline 4 & Minimum Moe productivity of the demarcated part (block) of the deposit & $\mathrm{m} \%$ & 0.15 \\
\hline
\end{tabular}

Several prospective areas with either prognostic or prospective resources have been selected for the region in question (Fig. 4, Table 7).

Nowa Wieś Żarecka-Myszków-Mrzygłód area surrounding the Myszków deposit (Piekarski et al. 1993; Podemski et al. 2001), covers an $27 \mathrm{~km}^{2}$ area and hence has prognostic resources in a belt $10 \mathrm{~km}$ long and 1 to $3 \mathrm{~km}$ wide, extending from Mrzygłód subarea in the south east, through Myszków subarea, to Nowa Wieś Żarecka subarea in the north west (Habryn et al. 1994).

The strict spatial and genetic relationship between the $\mathrm{Cu}-\mathrm{Mo}-\mathrm{W}$ mineralisation and the emplacement of granitoids and porphyries and the location of the Myszków deposit in the centre of the belt indicate a possibility to document further ore deposits in this prospective area. Based on the small surface area of this deposit and on the low density of the borehole grid, numerous orebodies comparable to the Myszków deposit may exist. One factor advantageous for exploration within the region in question is the shallow depth of the ore-bearing intervals (approximately $170 \mathrm{~m}$ below the surface). The entire prospective area is currently located within the Myszków-Żarki license area of the Silesian-Cracovian Metal Mining Company (Fig. 4), which is conducting drilling program there. With a higher density borehole grid, the examined subareas may constitute a reserve area for the Myszków mineral deposit in the event it is mined.

Będkowska Valley - an area with prospective resources, situated in the SW side of the Małopolska Block. The mineralization is dominated by polymetallic ores of porphyry type (Harańczyk 1980; Koszowska and Wolska 2000; Mikulski et al. 2007, 2008). Stockwork ores have not been found. Although the mineralisation is interesting from a mineralogical 


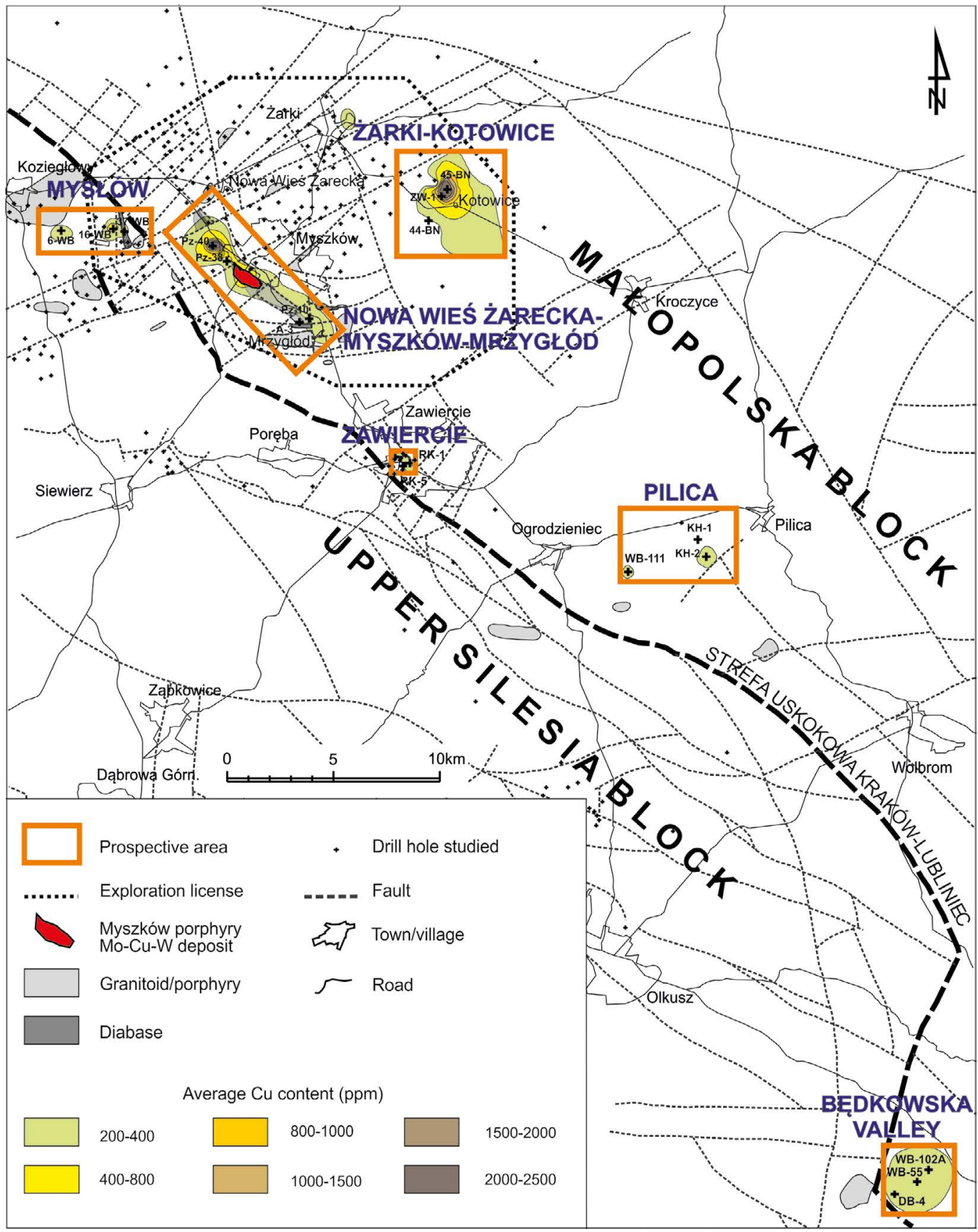

Fig. 4. Areas prospective with respect to the porphyry Mo-Cu-W and skarn deposits in the contact zone between the Upper Silesia and Małopolska blocks

Rys. 4. Obszary perspektywiczne mineralizacji miedziowej związanej z porfirowymi złożami Mo-Cu-W i złożami skarnowymi w strefie kontaktowej bloku górnośląskiego i małopolskiego 


\begin{tabular}{|c|c|c|c|c|c|c|c|c|c|c|c|c|c|}
\hline & 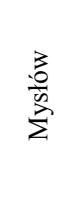 & $\stackrel{\tilde{\Xi}}{\Xi}$ & 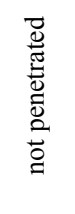 & 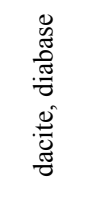 & 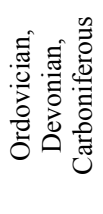 & 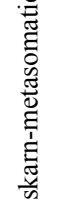 & $\begin{array}{l}\text { 莺 } \\
\text { 总 } \\
\text { 产 }\end{array}$ & $\begin{array}{l}\hat{\lambda} \\
\hat{0} \\
\sum_{1} \\
\hat{J}\end{array}$ & $\begin{array}{l}\overrightarrow{0} \\
\hat{\Lambda} \\
\hat{N}\end{array}$ & 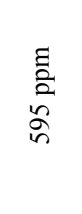 & $\begin{array}{l}\text { हे } \\
\stackrel{2}{a} \\
\bar{s} \\
\dot{\sigma}\end{array}$ & $\begin{array}{l}\text { हี } \\
\text { ב. } \\
\text { ते } \\
\text { ते }\end{array}$ & 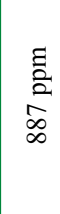 \\
\hline 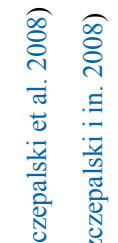 & 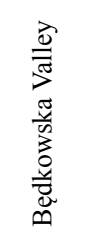 & $\stackrel{\tilde{E}}{\Xi}$ & 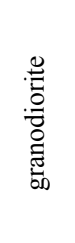 & 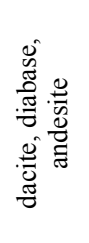 & 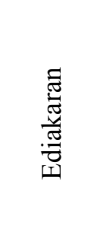 & 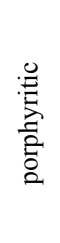 & 1 & $\begin{array}{l}\hat{\lambda} \\
\hat{0} \\
\sum_{1} \\
\hat{J}\end{array}$ & $\begin{array}{l}\vec{Z} \\
\hat{L} \\
\hat{2} \\
\hat{\Lambda} \\
\hat{N}\end{array}$ & $\begin{array}{l}\text { 言 } \\
\text { 心 } \\
\text { ळે }\end{array}$ & $\begin{array}{l}\text { हू } \\
\text { à } \\
\text { oे } \\
\text { ch }\end{array}$ & $\begin{array}{l}\text { 言 } \\
\text { 品 }\end{array}$ & 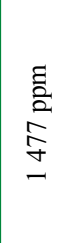 \\
\hline 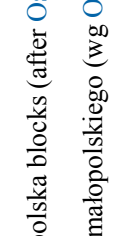 & 莺 & $\frac{\tilde{E}}{\mathrm{~g}}$ & 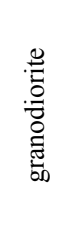 & 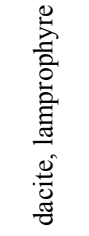 & 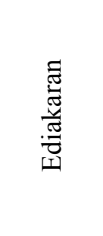 & 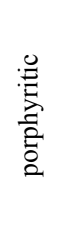 & 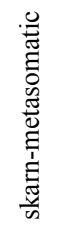 & $\begin{array}{l}\hat{\lambda} \\
\hat{0} \\
\sum_{1} \\
\hat{J}\end{array}$ & $\begin{array}{l}\text { D } \\
\hat{\Lambda} \\
\hat{N}\end{array}$ & 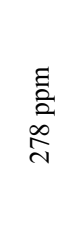 & 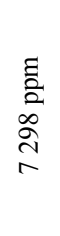 & 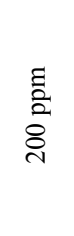 & $\begin{array}{l}\text { ․ } \\
\text { aे } \\
\infty \\
\infty \\
\infty \\
\infty\end{array}$ \\
\hline 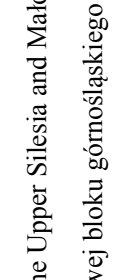 & 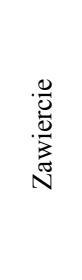 & $\begin{array}{l}\underset{\xi}{\tilde{E}} \\
\underset{-}{\sim}\end{array}$ & 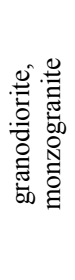 & 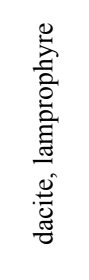 & 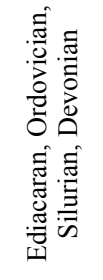 & 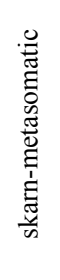 & 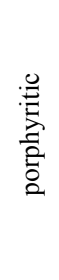 & $\begin{array}{l}\vec{B} \\
\hat{0} \\
\sum_{1} \\
\hat{J}\end{array}$ & $\begin{array}{l}\hat{N} \\
\hat{A} \\
\hat{\Omega}\end{array}$ & 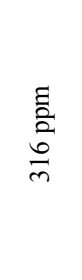 & 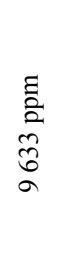 & $\begin{array}{l}\text { ह } \\
\text { 言 } \\
\text { b }\end{array}$ & 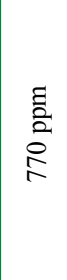 \\
\hline 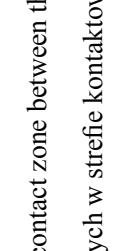 & 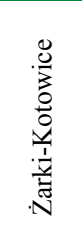 & 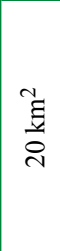 & 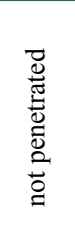 & 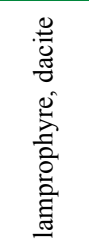 & 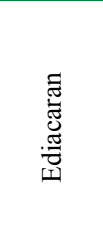 & 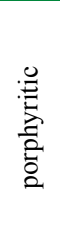 & 1 & $\begin{array}{l}\sum_{\lambda}^{0} \\
\hat{3} \\
\hat{\jmath} \\
\hat{J}\end{array}$ & $\begin{array}{l}\hat{N} \\
\hat{A} \\
\hat{\Omega}\end{array}$ & 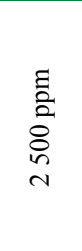 & 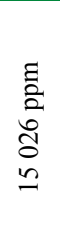 & 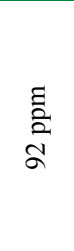 & 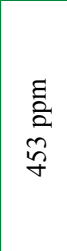 \\
\hline 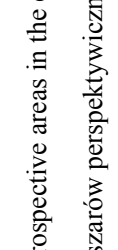 & 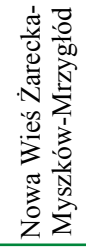 & $\frac{\tilde{E}}{\stackrel{\tilde{N}}{n}}$ & 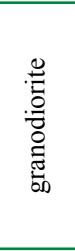 & 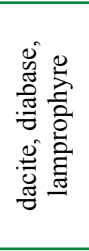 & 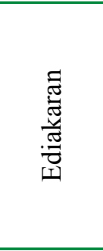 & 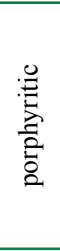 & 志 & $\begin{array}{l}3 \\
\hat{0} \\
\sum_{1} \\
\hat{J}\end{array}$ & $\begin{array}{l}\overrightarrow{0} \\
\hat{\Lambda} \\
\hat{N}\end{array}$ & 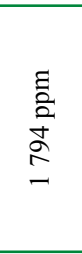 & 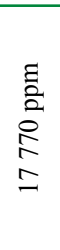 & 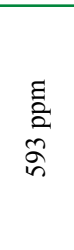 & 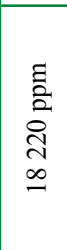 \\
\hline 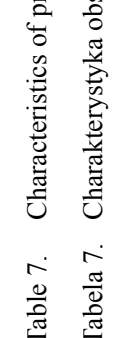 & 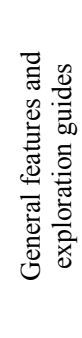 & 选 & 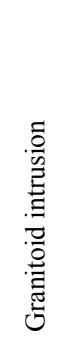 & 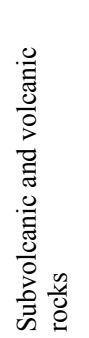 & 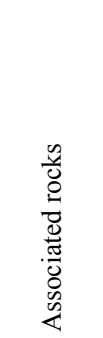 & 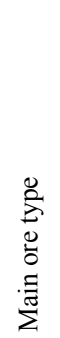 & 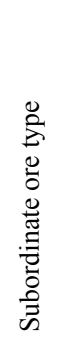 & 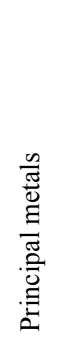 & 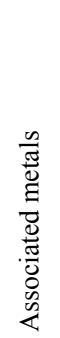 & 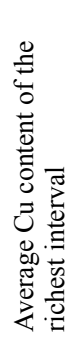 & 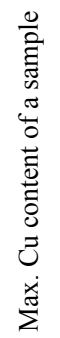 & 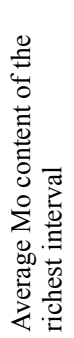 & 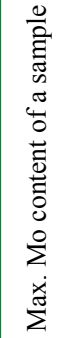 \\
\hline
\end{tabular}




\begin{tabular}{|c|c|c|c|c|c|c|c|c|c|c|c|}
\hline$\frac{\sqrt[3]{0}}{\frac{n_{0}^{2}}{2}}$ & 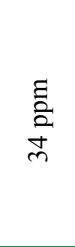 & 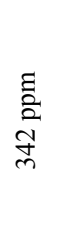 & $\begin{array}{l}\text { ㄹ. } \\
\text { in }\end{array}$ & 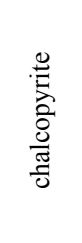 & 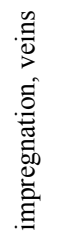 & 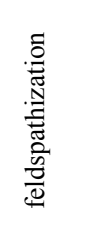 & 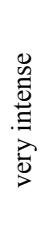 & 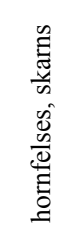 & $\frac{\stackrel{0}{0}}{\frac{\tilde{J}}{\tilde{J}}}$ & $\begin{array}{l}w \\
W \\
\Xi \\
\underline{\Xi} \\
I\end{array}$ & 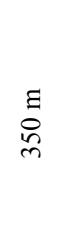 \\
\hline 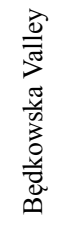 & $\begin{array}{l}\text { ह } \\
\text { à } \\
\text { ते }\end{array}$ & 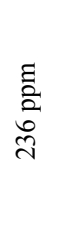 & $\begin{array}{l}\text { ڤे } \\
\vdots \\
\vdots \\
\vdots \\
n\end{array}$ & 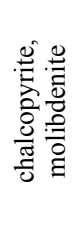 & 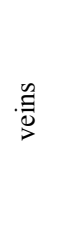 & 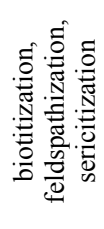 & 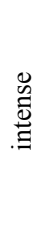 & 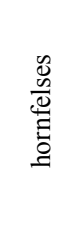 & 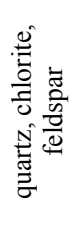 & $\begin{array}{l}\frac{1}{z} \\
\Xi \\
m \\
n \\
n\end{array}$ & $\stackrel{\Xi}{\Xi}$ \\
\hline 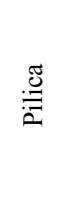 & $\begin{array}{l}\text { 言 } \\
\text { ल }\end{array}$ & 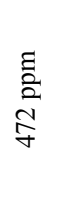 & $\begin{array}{l}\stackrel{2}{2} \\
\text { à }\end{array}$ & 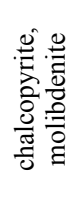 & 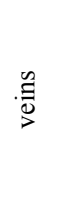 & 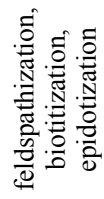 & 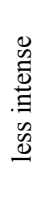 & 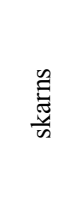 & 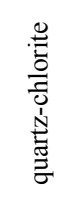 & $\begin{array}{l}\frac{1}{Z} \\
\frac{\Xi}{0} \\
0 \\
0\end{array}$ & 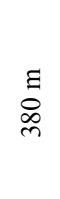 \\
\hline 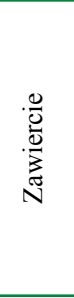 & $\begin{array}{l}\text { 言 } \\
\stackrel{0}{\varrho}\end{array}$ & $\frac{\bar{\Xi}}{\stackrel{\Xi}{a}}$ & $\begin{array}{l}\stackrel{0}{a} \\
\stackrel{a}{d}\end{array}$ & 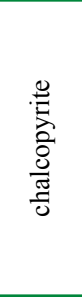 & 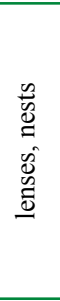 & 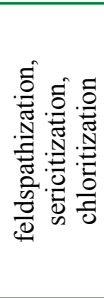 & 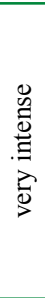 & 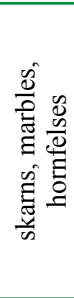 & 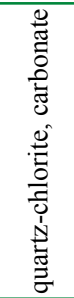 & $\begin{array}{l}\tilde{y} \\
\Xi \\
\Xi \\
\vdots \\
n \\
0\end{array}$ & $\stackrel{g}{\gtrless}$ \\
\hline 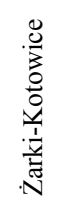 & $\begin{array}{l}\text { है } \\
\text { 2. } \\
0\end{array}$ & 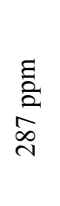 & $\frac{\stackrel{0}{a}}{\stackrel{i}{N}}$ & 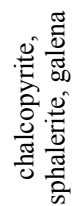 & 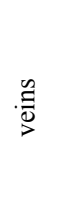 & 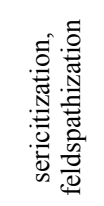 & 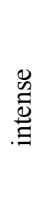 & 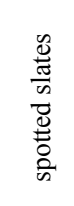 & 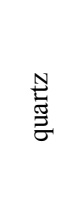 & 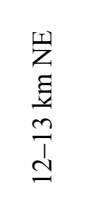 & 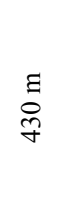 \\
\hline 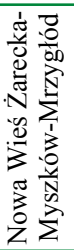 & $\begin{array}{l}\frac{\Xi}{2} \\
\stackrel{2}{m}\end{array}$ & 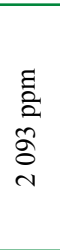 & $\begin{array}{l}\text { 을 } \\
\stackrel{2}{0}\end{array}$ & 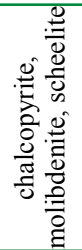 & 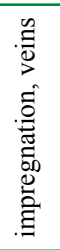 & 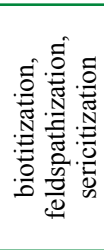 & 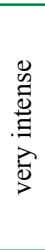 & 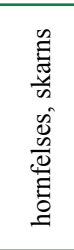 & 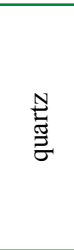 & 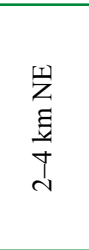 & $\begin{array}{l}\Xi \\
\stackrel{\Xi}{N} \\
\stackrel{1}{\Xi}\end{array}$ \\
\hline 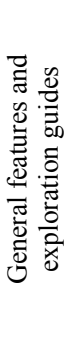 & 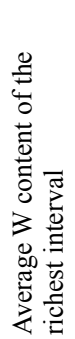 & 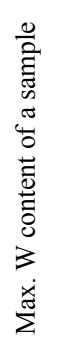 & 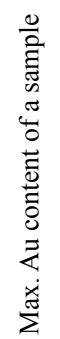 & 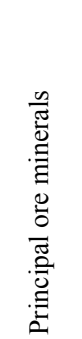 & 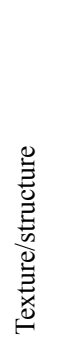 & 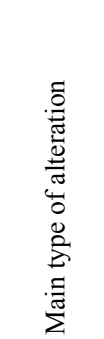 & 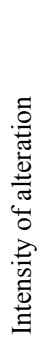 & 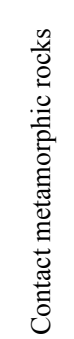 & 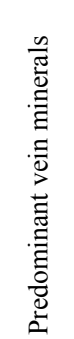 & 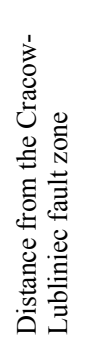 & 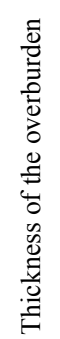 \\
\hline
\end{tabular}


point of view, it has no resource value given the current state of knowledge. It is possible that this mineralization continues to the east in the direction of the Cianowice- 2 drill hole, in which poor mineralization was found in the Ediacaran rocks (Markowiak 2014).

Myslów - an area with prospective resources located in the NE margin of the Upper Silesia Block, within the zone of overlapping tectonic fragments of the Upper Silesia and Małopolska blocks. The $\mathrm{Cu}$, Mo and $\mathrm{W}$ minerals are relatively scarce compared to the other prospective areas, however the region has not been yet sufficiently investigated in terms of drilling. It cannot be ruled out that this area constitutes a peripheral zone of a yet unidentified orebody, which may be expected to be found within the most heavily uplifted tectonic block in eastern subarea. Less rich mineralization was examined southwest of the area in question (Pańczyk et al. 2012).

Pilica - an area with prospective resources, demarcated by two boreholes with porphyry-type mineralisation (Harańczyk 1980; Piekarski 1994a). The sparse grid of boreholes drilled and significant core losses do not allow for a full evaluation. This mineralisation is irregularly distributed mostly in a form of veinlets crosscutting magmatic rocks and Ediacaran metasediments. Vast $\mathrm{W}$ and $\mathrm{Bi}$ anomalies as well as individual $\mathrm{Cu}, \mathrm{Zn}, \mathrm{Ba}$ and $\mathrm{Sr}$ anomalies suggest the presence of a magmatic intrusion near the Kraków-Lubliniec fault zone. Further exploration would be facilitated by the relatively shallow depth of the top of the Ediacaran (>195 m), but limited by the considerable depth of both the top of the ore-bearing intervals (ranging between 380 and $440 \mathrm{~m}$ ) and the top of the granitoids ( $>419 \mathrm{~m}$ ).

Zawiercie - an area with prospective resources that are located in the marginal part of the Małopolska Block, immediately adjacent to the Kraków-Lubliniec tectonic zone (Harańczyk et al. 1980; Piekarski 1994b). In spite of its small surface area $\left(1.2 \mathrm{~km}^{2}\right)$, it is the best explored region in terms of drilling, with over 40 boreholes, 9 of which are characterised by abundant ores. This area itself is interesting, however at the current stage of knowledge, it does not present any considerable value as a mineral deposit because the skarn and porphyry mineralisation form irregular orebodies and veins. Demarcating a proper concession area, conducting new drilling operations and possibly documenting the metal ore resources could lead to receiving an economic benefit from the potential mineral deposit, provided that mining is possible and profitable in the area of complex geological structure under the conditions of underground mining below urban areas.

Żarki-Kotowice - an area with prospective resources contained by Ediacaran rocks. It is located SE of Żarki, approximately $10 \mathrm{~km}$ from the Kraków-Lubliniec fault zone. In this region, drilled granitoid intrusions have not been found; however, due to the presence of high temperature mineralization and metasomatic alteration, the presence of granitoid intrusions is not excluded (Lasoń and Markowiak 2008; Karwowski and Markowiak 2012). Sparse boreholes and the small thickness of penetrated Ediacaran rocks do not allow for a full exploration prognosis. One of the factors limiting the understanding of this region is the considerable thickness of the Mesozoic overburden (400-500 m). This prognosis will be verified as a result of drilling program conducted within the concession area by the Silesian-Cracovian Metal Mining Company. 


\section{Concluding comments}

The potential of extending the resource base of mineral deposits puts Poland in the group of countries, which significance is crucial to European Union's reindustrialisation. Polish documented resources meeting the official criteria amount to approx. $1761.96 \mathrm{Mt}$ of ore containing 33.78 Mt of copper and 103.18 thousand tonnes of silver. It has been estimated that in SW Poland, apart from the documented copper ore deposits, there can be approx. $179 \mathrm{Mt}$ of $\mathrm{Cu}$ and 346 thousand tonnes of $\mathrm{Ag}$ constituting resources that are prospective for future use in the mining industry, provided that geological and technological limitations (depth, temperature, oil and gas) do not pose barriers affecting the economic trends in the global market. For those reasons, it is extremely essential to verify the resource estimates for prospective areas by exploration drilling, which would make it possible in the future to make use preferentially of the prognostic resources in the nearest vicinity of the Lubin-Sieroszowice and Myszków deposits, as well as the most appealing prospective resources.

It should be noted that the irregular grid of examined boreholes results in simplification of the extents of prospective areas and in likely overestimation or underestimation of the presumed resources. Numerous very deep drilling programs are necessary to verify the resource potential within the areas of many exploration concessions - both granted and applied for. Prospecting activities including drillings have already commenced in some of the license areas. In order for those areas to be used for future mining, it is essential that they are first precisely identified and documented. The extraction from depths reaching $2000 \mathrm{~m}$ will require application of cutting-edge technology, provision of advantageous investing conditions and preparation of long-term mineral resource strategy with respect to both the country and the European Union.

\section{REFERENCES}

Bachowski et al. 2011 - Bachowski, C., Kudełko, J. and Wirth, H. 2011. Baza krajowych zasobów złóż rud miedzi i perspektywy jej rozwoju. [In:] Banaszak A. et al. ed. Geolodzy w stużbie Polskiej Miedzi. Konferencja Środowiskowa Geologów, Lubin, 24 marca 2011 r., pp. 91-106.

Bossowski, A. ed. 1982. Rudy miedzi. [In:] Zasoby perspektywiczne kopalin Polski. Warszawa: Wyd. Geologiczne, pp. 153-206.

Buła et al. 2002 - Buła Z., Habryn R., Krieger W., Kurek S., Markowiak M. and Woźniak P. 2002 - Atlas geologiczny paleozoiku bez permu w strefie kontaktu bloków górnośląskiego i małopolskiego. Warszawa: PIG.

Ekiert, F. 1971. Budowa geologiczna podpermskiego podłoża północno-wschodniego obrzeżenia Górnośląskiego Zagłębia Węglowego. Prace Inst. Geol. 66, pp. 5-77.

Galos et al. 2012 - Galos, K., Nieć, M., Radwanek-Bąk, B., Smakowski, T. and Szamałek, K. 2012. Bezpieczeństwo surowcowe Polski w Unii Europejskiej i na świecie. Biul. Państw. Inst. Geol. 452, pp. 43-52.

Gospodarczyk, E. 1976. Rudy miedzi. [In:] Zasady prognozowania i zasoby perspektywiczne kopalin Polski. Wyd. Geologiczne.

Górecka, E. and Nowakowski, A. 1979. Ore deposits associated with acid intrusives and related rocks in the Zawiercie region. Prace Inst. Geol. 95, pp. 97-107. 
Habryn et al. 1994 - Habryn, R., Markowiak M. and Ślósarz J. 1994. Perspektywy udokumentowania nowego ciała rudnego w kierunku na NW od złoża molibdenowo-wolframowo-miedziowego Myszków. Przegląd Geologiczny 42(8), pp. 611-614.

Harańczyk, C. 1980. Palaeozoic porphyry copper deposits in Poland. SGA Spec. Publ. 1, pp. 89-95.

Harańczyk et al. 1980 - Harańczyk, C., Gałkiewicz, C., Kurek, S., Rogoż, S. and Szostek, L. 1980. Porfirowa i skarnowa mineralizacja z Zawiercia. Część II. Mineralizacja. Rudy Met. Nieżel. 25(12), pp. 558-565.

Karwowski, Ł. and Markowiak, M. 2012. Przejawy mineralizacji polimetalicznej w utworach ediakarskich rejonu Żarki-Kotowice. Mineralogia 43(3-4), pp. 199-212.

Karwowski et al. 2005 - Karwowski, Ł., Lasoń, K., Markiewicz, J. and Truszel, M. 2005. Geochemiczno-petrologiczne przesłanki Mo-W-Cu mineralizacji typu złóż porfirowych rejonu krakowsko-lublinieckiego. Przew. 76 Zjazdu Pol. Tow. Geol. Rudy k. Rybnika, pp. 75-79. Warszawa.

Koszowska, E. and Wolska, A. 2000. Mineralogical and geochemical study of thermally altered country rocks of granodiorite intrusion in the Będkowska Valley near Kraków (S Poland). Ann. Soc. Geol., Pol. 70, $261-281$.

Krzemiński, P. and Speczik S. 2013. Prognostyczne złoże rud Cu-Ag w województwie lubuskim (SW Polska). Zeszyty Naukowe IGSMiE PAN, 85, pp. 231-240.

Lasoń, K. 1992. Strefowość mineralizacji polimetalicznej paleozoiku okolic Myszkowa (NE obrzeżenie GZW) Arch. Mineral. 48(1-2), pp. 43-59.

Lasoń, K. and Markowiak, M. 2008. Perspektywy odkrycia ciała rudnego w rejonie Żarki-Kotowice w świetle badań petrograficzno-geochemicznych. Biul. Państ. Inst. Geol. 430, pp. 65-78.

Lipień et al. 2014 - Lipień, G. Sokalski, D. and Tylka, M. 2014. Plany powiększenia krajowej bazy zasobowej rud miedzi KGHM Polska Miedź S A. XXIV Konferencja „Aktualia i perspektywy gospodarki surowcami mineralnymi", Zakopane, 5-7 listopada 2014 (niepublikowany referat).

Malon et al. 2014 - Malon, A., Tymiński, M., Mikulski, S.Z. and Oszczepalski, S. 2014. Surowce metaliczne. [In:] Szuflicki, M. et al. ed. Bilans zasobów złóż kopalin w Polsce według stanu na 31.XII.2013 r. Państwowy Instytut Geologiczny - Państwowy Instytut Badawczy, pp. 51-68.

Markiewicz et al. 1993 - Markiewicz, J., Ślósarz, J. and Truszel, M. 1993. Pozycja geologiczna mineralizacj Cu-Mo-W w paleozoiku północno-wchodniego obrzeżenia GZW. Pr. Spec. PTMin. 3, pp. 47-54.

Markowiak, M. 2005. Charakterystyka przejawów polimetalicznej mineralizacji kruszcowej w strefie kontaktu bloków górnośląskiego i małopolskiego. Przew. 76 Zjazdu Pol. Tow. Geol. Rudy k. Rybnika, pp. 177-182.

Markowiak, M. 2014. Przejawy mineralizacji kruszcowej w skałach nawierconych otworami Trojanowice 2 i Cianowice 2. Biul. Państw. Inst. Geol. 459, pp. 83-92.

Markowiak et al. 1994 - Markowiak, M., Piekarski, K., Ślósarz, J., Habryn, R., Markiewicz, J., Truszel, M., Lasoń, K., Jura, D. and Badera, J. 1994. Wyniki badań geologicznch i złożowych paleozoicznego podłoża w obszarze Myszków-Mrzygłód. Przewodnik 65 Zjazdu Pol. Tow. Geol. w Sosnowcu, Pr. Nauk. UŚl. 1431, pp. $173-217$.

Mikulski et al. 2007 - Mikulski, S.Z., Markowiak, M. and Oszczepalski, S. 2007. Preliminary results of geochemical and ore-microscopic studies of Mo-Cu mineralization from the Bedkowska Valley near Kraków (Poland). [In:] Colin, J.L. et al. ed. Digging deeper, Proceedings of the Ninth Biennial SGA Meeting, Dublin 2007, pp. $447-450$

Mikulski et al. 2008 - Mikulski, S.Z., Markowiak, M. i Oszczepalski, S. 2008. Złoto w żyłach kwarcowo-siarczkowych z wiercenia DB-4 (rejon Doliny Będkowskiej, południowa Polska). Biul. Państ. Inst. Geol. 429, pp. 99-112.

Nieć, M. 1988. Szanse odkrycia złóż rud metali w starszym podłożu paleozoicznym NE obrzeżenia Górnośląskiego Zagłębia Węglowego. Przegląd Geol. 36(7), pp. 390-395.

Oszczepalski, S. 1989. Kupferschiefer in southwestern Poland: sedimentary environments, metal zoning, and ore controls. [In:] Boyle, R.W. et al. ed. Sediment-hosted stratiform copper deposits, Geological Association of Canada Special Paper, 36, pp. 571-600.

Oszczepalski, S. 1999. Origin of the Kupferschiefer polymetallic mineralization in Poland. Mineralium Deposita 34, pp. 599-613.

Oszczepalski, S. and Rydzewski, A. 1983. Miedzionośność utworów permu na obszarze przylegającym do złoża Lubin-Sieroszowice. Przeglad Geologiczny 31(7), pp. 437-444.

Oszczepalski, S. and Rydzewski, A. 1991. The Kupferschiefer mineralization in Poland. Zentralblatt für Geologie und Paläontologie, Teil I, H.4, pp. 975-999. 
Oszczepalski, S. and Rydzewski, A. 1993. Rudy miedzi. [In:] Bąk, B. and Przeniosło, S. ed. Zasoby perspektywiczne kopalin Polski wg stanu na 31 XII 1990, pp. 98-116.

Oszczepalski, S. and Rydzewski, A. 1997. Atlas metalogeniczny cechsztyńskiej serii miedzionośnej w Polsce. Państwowy Instytut Geologiczny - Wydawnictwo Kartograficzne Polskiej Agencji Ekologicznej SA, Warszawa.

Oszczepalski, S. and Rydzewski, A. 2007. Rozmieszczenie metali w basenie cechsztyńskim. [In:] Piestrzyński, A. et al. ed. Monografia KGHM Polska Miedź SA, wydanie II, pp. 95-101. Allexim sp. z o.o., Wrocław.

Oszczepalski, S. and Speczik, S. 2011a. Rudy miedzi i srebra. [In:] Wołkowicz, S. et al. ed. Bilans perspektywicznych zasobów kopalin Polski wg stanu na 31.XII.2009 r., pp. 76-93. Warszawa: PIG.

Oszczepalski, S. and Speczik, S. 2011b. Prospectivity analysis of the Polish Kupferschiefer - new insight. [In:] Barra, F. et al. ed. Let's Talk Ore Deposits, 11th SGA Biennial Meeting, Antofagasta, 26-29th September 2011, pp. 294-296.

Oszczepalski, S. and Speczik, S. 2014. Perspektywiczna baza zasobowa rud miedzi w Polsce. [In:] Rola Polski w zwiększaniu bezpieczeństwa surowcowego Unii Europejskiej, Sopot 1-3 października 2014, pp. 5-23. Polski Związek Pracodawców Przemysłu Wydobywczego.

Oszczepalski et al. 1996 - Oszczepalski, S., Rydzewski, A. and Banaszak, A. 1996. Stan badań utworów cechsztynu w Polsce - perspektywy odkrycia nowych obszarów metalonośnych. [In:] Uroczysta Sesja Naukowa, 40-lecie odkrycia złóż rud miedzi i 35-lecie KGHM Polska Miedź SA, Warszawa-Lubin 1996, pp. 17-23.

Oszczepalski et al. 2008 - Oszczepalski, S., Markowiak, M., Buła, Z., Lasoń, K., Mikulski, S.Z., Habryn, R., Truszel, M., Pańczyk, M., Sikora, R., Woźniak, P., Mucha, J., Wasilewska, M., Karwowski, Ł., Markiewicz, J., Wojciechowski, A., Urbański, P., Saternus, A., Cudak, J. and Brański, P. 2008. Prognoza złożowa podłoża paleozoiczno-prekambryjskiego NE obrzeżenia GZW. Warszawa: NAG.

Oszczepalski et al. 2010a - Oszczepalski, S., Markowiak, M., Mikulski, S.Z., Lasoń, K., Buła, Z. and Habryn, R. 2010. Porfirowa mineralizacja Mo-Cu-W w utworach prekambryjsko-paleozoicznych - analiza prognostyczna strefy kontaktu bloków górnośląskiego i małopolskiego. Biul. Państw. Inst. Geol. 439, pp. 339-354.

Oszczepalski et al. 2010b - Oszczepalski, S., Speczik, S., Chmielewski, A. and Krzemiński, P. 2010. Ocena możliwości poszerzenia bazy zasobowej - poszukiwanie nowych rezerw w otoczeniu złoża Lubin-Sieroszowice. NAG, Warszawa.

Oszczepalski et al. 2012 - Oszczepalski, S., Chmielewski, A., Sowula, W., Boratyn, J., Pikuła, K. and Zieliński, K. 2012. Ocena możliwości występowania cechsztyńskiej mineralizacji $\mathrm{Cu}-\mathrm{Ag}$ na obszarze województw lubuskiego i wielkopolskiego na podstawie archiwalnych materiałów wiertniczych, w tym wierceń naftowych. Warszawa: NAG.

Pańczyk et al. 2012 - Pańczyk, M., Markowiak, M., Zieliński M. and Giro, L. 2012. Mineralizacja kruszcowa w obrębie zmetasomatyzowanej intruzji magmowej w rejonie Koziegłów (blok górnośląski). Biuletyn Państw. Inst. Geol. 448(2), pp. 359-370.

Piekarski, K. 1971. Perspektywy występowania złóż miedziowo-molibdenowych w utworach staropaleozoicznych północno-wchodniego obrzeżenia GZW. Kwart. Geol. 15(3), pp. 710-711.

Piekarski, K. 1983. Analiza metalogeniczno-prognostyczna utworów paleozoicznych północno-wschodniego obrzeżenia Górnośląskiego Zagłębia Węglowego. Rocz. Pol. Tow. Geol. 53, pp. 207-234.

Piekarski, K. 1994a. Ocena wyników poszukiwań złóż polimetalicznych obszaru Pilicy. Przegląd Geol. 42(8), pp. 621-624.

Piekarski, K. 1994b. Ocena wyników poszukiwań złóż rud polimetalicznych w utworach staropaleozoicznych obszaru Zawiercia. Przeglad Geol. 42(8), pp. 615-620.

Piekarski et al. 1993 - Piekarski, K., Gajowiec, B., Habryn, R., Karwasiecka, M., Kurbiel, H., Łuszczkiewicz, A., Markiewicz, J., Markowiak, M., Siemiński, A., Stępniewski, M. and Truszel, M. 1993. Dokumentacja geologiczna złoża rud molibdenowo-wolframowo-miedziowych Myszków w kategorii C2. NAG Warszawa.

Podemski et al. 2001 - Podemski, M., Buła, Z., Chaffee M.A., Cieśla, E., Eppinger, R., Habryn, R., Karwowski, Ł., Lasoń, K., Markiewicz, J., Markowiak, M., Snee, L.W., Ślósarz, J., Truszel, M., Wybraniec, S. and Żaba, J. 2001. Palaeozoic porphyry molybdenum-tungsten deposit in the Myszków area, southern Poland. PGI Special Papers 6, $87 \mathrm{pp}$.

Rozporządzenie Ministra Środowiska z dnia 20 czerwca 2005 r. zmieniające rozporządzenie w sprawie kryteriów bilansowości złóż kopalin (Dz.U. 2005 nr 116, poz. 978). 
Rozporządzenie Ministra Środowiska z dnia 22 grudnia 2011 r. w sprawie dokumentacji geologicznej złoża kopaliny (Dz.U. $2011 \mathrm{nr}$ 291, poz. 1712).

Rydzewski, A. 1969. Petrografia łupków miedzionośnych cechsztynu na monoklinie przedsudeckiej. Biul. Inst. Geol. 217, pp. 113-167.

Rydzewski, A. 1978. Facja utleniona cechsztyńskiego łupku miedzionośnego na obszarze monokliny przedsudeckiej. Przegląd Geologiczny 26, pp. 102-108.

Rydzewski et al. 1996 - Rydzewski, A., Banaszak, A. and Oszczepalski, S. 1996. Obszary perspektywiczne dla złóź miedzi. [In:] Piestrzyński, A. et al. ed. Monografia KGHM Polska Miedź SA, pp. 332-339.

Smakowski, T. and Szamałek, K. 2011. Zasady określania zasobów perspektywicznych kopalin. [In:] Wołkowicz, S. et al. ed. Bilans perspektywicznych zasobów kopalin Polski wg stanu na 31 XII 2009 r., pp. 11-15. Warszawa: PIG.

Speczik, S. 1995 - The Kupferschiefer mineralization of Central Europe: New aspects and major areas of future research. Ore Geol. Rev. 9, pp. 411-426.

Speczik, S. and Oszczepalski, S. 2011. Złoża prognostyczne rud miedzi na monoklinie przedsudeckiej - nowa perspektywa. [In:] Banaszak, A. et al. ed. Geolodzy w stużbie Polskiej Miedzi, Konferencja Środowiskowa Geologów, Lubin, 24 marca 2011 r., pp. 67-84.

Speczik et al. 1998 - Speczik, S., Rydzewski, A. and Oszczepalski, S. 1998. Badania cechsztynu miedzionośnego w SW Polsce: strategia i perspektywy poszukiwawcze. PTMin. - Prace Spec. 10, pp. 93-104.

Speczik et al. 2007 - Speczik, S., Oszczepalski, S., Karwasiecka, M and Nowak, G.J. 2007. Kupferschiefer - A hunt for new reserves. [In:] Andrew, C.J. ed. Digging deeper, Proceedings of the Ninth Biennial SGA Meeting, Dublin 2007, pp. 237-240.

Speczik et al. 2011 - Speczik, S., Oszczepalski, S., Chmielewski, A., Krzemiński, P., Karwasiecka, M., Nowak, G., Dziewińska, L., Jóźwiak, W. and Bojakowska, I. 2011. Analiza i ocena obszarów zlokalizowanych w kierunku pótnocno-wschodnim od koncesyjnych obszarów górniczych KGHM PM SA, pod kątem możliwości udokumentowania zasobów rudy miedzi spetniających kryteria ekonomiczne i wytypowania celów do dalszej eksploatacji. Arch. KGHM CUPRUM sp. z o.o.

Speczik et al. 2013 - Speczik, S., Oszczepalski, S. and Chmielewski, A. 2013. Exploration and mining perspective of the Kupferschiefer series in SW Poland: digging deeper? [In:] Erik Jonsson, E. et al. ed. Mineral deposit research for a high-tech world, Proceedings of the 12th Biennial SGA Meeting, 12-15 August 2013, Uppsala, Sweden, 2, pp. 687-690.

Speczik et al. 2014 - Speczik, S., Oszczepalski, S. and Małecka, K. 2014. Nowe dane na temat bazy zasobowej rud miedzi i srebra w Polsce. Zeszyty Naukowe IGSMiE PAN, 88, pp. 235-249.

Ślósarz, J. 1982. Uwagi o warunkach geologicznych mineralizacji Cu-Mo w paleozoiku okolic Myszkowa. Przegląd Geologiczny 30(7), pp. 329-335.

Ślósarz, J. 1993. Główne zespoły paragenetyczne mineralizacji molibdenowej w paleozoiku okolic Myszkowa, ich kontrola i znaczenie rudonośne. Pr. Spec. PTMin. 3, pp. 123-128.

Truszel et al. 2006 - Truszel, M., Karwowski, Ł., Lasoń, K., Markiewicz, J. and Żaba, J. 2006. Magmatyzm i metamorfizm strefy tektonicznej Kraków-Lubliniec jako przesłanki występowania złóż polimetalicznych. Biul. Państw. Inst. Geol. 418, pp. 55-103.

Wirth et al. 2007 - Wirth, H., Banaszak, A., Rydzewski, A. and Oszczepalski, S. 2007. Obszary rezerwowe i perspektywiczne dla złóż miedzi. [In:] Piestrzyński, A. et al. ed. Monografia KGHM Polska Miedź SA, wydanie II, pp. 263-269. Wrocław: Allexim sp.z o.o.

Wyżykowski, J. 1958. Poszukiwania rud miedzi na obszarze strefy przedsudeckiej. Przegląd Geol. 6(1), pp. 17-22.

Wyżykowski, J. 1971. Dotychczasowe wyniki geologicznych prac badawczych a dalsze perspektywy stwierdzenia nowych złóż rud miedzi w Polsce. Cuprum, 12, pp. 20-29.

Zientek et al. 2015 - Zientek, M.L., Oszczepalski, S., Parks, H.L., Bliss, J.D., Borg, G., Box, S.E., Denning, P.D., Hayes, T.S., Spieth, V. and Taylor, C.D. 2015. Assessment of undiscovered copper resources associated with the Permian Kupferschiefer, Southern Permian Basin, Europe: U.S. Geological Survey Scientific Investigations Report 2010-5090-U, 94 pp. 
PERSPEKTYWICZNA BAZA ZASOBOWA MIEDZI W POLSCE

Słowa kluczowe

stratyfikowane złoża miedzi, porfirowe złoża miedzi, eksploracja,

obszary perspektywiczne

\section{Streszczenie}

Najistotniejsze zasoby miedzi w Polsce umiejscowione są w stratoidalnych złożach typu łupka miedzionośnego, udokumentowanych w utworach strefy kontaktowej czerwonego spągowca i cechsztynu na monoklinie przedsudeckiej i w niecce północnosudeckiej. Wyniki najnowszych badań rdzeni licznych otworów wiertniczych wyraźnie wskazują, że permską serię miedzionośną cechuje znaczny potencjał zasobowy w postaci zasobów prognostycznych, perspektywicznych i hipotetycznych.

Wyznaczono 38 obszarów perspektywicznych (w tym 6 obszarów z zasobami prognostycznymi, 4 z zasobami perspektywicznymi i 28 obszarów z zasobami hipotetycznymi). Wśród obszarów perspektywicznych szczególną uwagę zwracają obszary z zasobami prognostycznymi (Białołęka, Grochowice, Kulów, Luboszyce), przylegające bezpośrednio do udokumentowanych złóż rud miedzi. Ponadto, obszary: Nowiny, Żarków i Mirków są interesujące ze względu na korzystną głębokość oraz obszar Mozów, który zawiera bogatą mineralizację rozciągającą się prawdopodobnie w kierunku południowo-wschodnim, poprzez obszary perspektywiczne Jany i Grochowice, aż do kopalń w obrębie złoża Lubin-Sieroszowice. Oszacowano, że około 179 mln t Cu i 346 tys. t Ag może znajdować się na obszarach perspektywicznych SW Polski dla przemysłu górniczego w przyszłości, pod warunkiem, że geologiczne i technologiczne ograniczenia (głębokość, temperatura, ropa i gaz) nie będą stanowić istotnych barier dla trendów gospodarczych światowego rynku. Spodziewany postęp w technologii podziemnego górnictwa na głębokości poniżej 1500 m (dopuszczalna głębokość dla zagospodarowania zasobów) pozwoli efektywnie wydobyć rudy z takich głębokości.

Następnych sześć obszarów perspektywicznych wyznaczono w strefie kontaktowej bloku górnośląskiego i małopolskiego, gdzie występuje mineralizacja $\mathrm{Mo}-\mathrm{Cu}-\mathrm{W}$ typu porfirowego (lokalnie ze skarnami) w obrębie skał systemu granitoidowo-porfirowego oraz w skałach metamorficznych i osadowych ediakaru, ordowiku, syluru, dewonu i karbonu.

Należy zauważyć, że nieregularna siatka zbadanych wierceń skutkuje uproszczeniem zasięgów obszarów perspektywicznych oraz prawdopodobnym przeszacowaniem przypuszczalnych zasobów. Liczne programy wiertnicze do dużych głębokości są niezbędne, aby zweryfikować potencjał zasobowy na obszarach wielu przyznanych i wnioskowanych koncesji poszukiwawczych. Długoterminowe wyzwania wymagają nowych rozwiązań dla górnictwa przyszłości i rynku gospodarczego UE, aby umożliwić reindustrializację Europy. 
PROSPECTIVE COPPER RESOURCES IN POLAND

\author{
Keywords
}

stratiform copper deposits, porphyry copper deposits, exploration, prospective areas

\title{
Abstract
}

The most significant copper reserves in Poland are confined to sediment-hosted stratiform Kupferschiefer-type deposits that occur at the Zechstein/Rotliegendes transition in the Fore-Sudetic Monocline and North-Sudetic Trough. Gradual depletion of shallow reserves results in exploitation of deeper beds. Latest studies of numerous drill hole cores strongly indicate that the Kupferschiefer series in SW Poland (outside the Lubin-Sieroszowice Copper District) contains a very large volume of prognostic, prospective and hypothetical resources.

38 prospects have been delineated (including 6 areas with prognostic resources, 4 with prospective resources, and 28 areas with hypothetical resources). Among the prospective areas, particular attention is paid to the areas adjacent to the existing mines of Lubin-Sieroszowice copper district, with prognostic resources (Białołęka, Grochowice, Kulów, Luboszyce). Also the areas: Nowiny, Żarków and Mirków are interesting due to accessible depths, Sulmierzyce and Janowo areas due to considerable resources and reasonable depth, and Mozów area - because of high $\mathrm{Cu}-\mathrm{Ag}$ grading mineralized body with credible continuation to south east through Jany and Grochowice prospects, towards the Lubin-Sieroszowice mining district. It can be estimated that approximately 179 million tons $\mathrm{Cu}$ and 346 thousand tons Ag concentrated as potential resources in prospects of SW Poland for future mining, which will be possible, when geological and technological barriers (depth, temperature, oil and gas) will meet economic trends in the world market. Expected progress in underground mining at depths exceeding $1500 \mathrm{~m}$ (a depth limit for economic categories) will make this approach effective and technically possible.

Additional six prospective areas have been delineated in the contact zone between Upper Silesia and Małopolska blocks, where porphyry-type $\mathrm{Mo}-\mathrm{Cu}-\mathrm{W}$ mineralization (locally with skarns) occurs within porphyry/granitoid rocks and Ediacaran, Ordovician, Silurian, Devonian and Carboniferous metasediments and other sedimentary formations.

It should be noted, however, that irregular network of examined drill holes tended to simplify the ranges of prospects and to overestimate resource evaluation. Extensive deep exploration drilling is required to verify resource potential of granted and applied exploration licenses in several targets. The long-term challenges require new solutions for mining industry of the future and industrial market within the EU, to enable the reindustrialization of Europe. 